\title{
APPLICATION OF CONCAVE INDUCTION COOKING TO IMPROVE THE TEXTURE AND FLAVOR OF BRAISED PORK
}

\section{Dandan $\mathrm{Da}^{1,2,3,4}$, Chunbao $\mathrm{Li}^{1,2,3,4 *}$ \\ ${ }^{1}$ Key Laboratory of Meat Processing and Quality Control, MOE, Nanjing, China \\ ${ }^{2}$ Key Laboratory of Meat Processing, MARA, Nanjing, China}

${ }^{3}$ Jiangsu Collaborative Innovation Center of Meat Production and Processing, Quality and Safety Control, Nanjing, China ${ }^{4}$ College of Food Science and Technology, Nanjing Agricultural University, Nanjing, China

Keywords: concave induction, oxidation, flavor, texture, fatty acid, E-nose

\begin{abstract}
Long-term cooking may reduce the eating and nutritional quality attributes of meat products due to excessive oxidation. This study aimed to investigate the feasibility of concave induction to improve the quality of braised pork belly. Pork belly cubes were subjected to concave induction cooking $(2000 \mathrm{~W}$ ) or plane induction cooking (2000 W, traditional) for $60 \mathrm{~min}, 90 \mathrm{~min}, 120 \mathrm{~min}$ or $150 \mathrm{~min}$. Then texture, fatty acid profile, lipid and protein oxidation, volatile flavor and sensory test in braised meat were evaluated. Compared with traditional method, concave induction cooking showed higher heating performance with shorter time to achieve a setting temperature. Compared with traditional cooking for 150 min, concave induction cooking for 60 min did not only produce a comparable volatile flavor and sensory scores, but also give better quality attributes, including lower hardness, chewiness, thrombogenicity values, PUFA/SFA value, lipid and protein oxidation. E-nose results showed that samples cooked by concave induction for 60 min and $90 \mathrm{~min}$ showed a great similarity to those cooked by plane induction for $150 \mathrm{~min}$. Concave induction cooking for $60 \mathrm{~min}$ also showed advantages to retain higher abundances of other volatile compounds including 2-pentylfuran, (E, E)-3,5-octadien-2-one, 2, 3-octanedione, 2-decahydro-1,6- dimethylnaphthalene when compared with plane induction cooking for 150 min.
\end{abstract}

For citation: Da, D., Li, C. (2021). Application of concave induction cooking to improve the texture and flavor of braised pork. Theory and practice of meat processing, 6(4), 354-367. https://doi.org/10.21323/2414-438X-2021-6-4-354-367

\section{Funding:}

This work was supported by Ministry of Science and Technology of the People's Republic of China (2017YFD0400103), Jiangsu Provincial Department of Finance (CX(18)2024) and China Agriculture Research System of MOF and MARA (CARS35).

\section{Introduction}

Induction heating is a technology that generates an electric current in the heated material using electromagnetic induction [1]. It has been widely applied to kitchens and food industry because of good uniformity, high efficiency and high safety $[2,3]$ observed that the protein and fat contents were higher in roast beef, baked beans and steamed salmon by induction heating than by traditional cooking. Induction heating also showed higher efficiency in extracting pectin from plants than traditional methods [4], and sterilization for ketchup [5].

Induction heating equipment used for cooking mainly includes plane induction cooker [6] and concave induction cooker [7]. The plane induction cooker is suitable for family and small-scale food preparation, while the concave induction cooker is more suitable for factory processing and has a promising industrial application. It has been shown that the concave induction cooker has higher heating efficiency and uniformity compared with plane induction cooker [8]. However, it is still little studied how concave induction cooking affect food quality and flavor.
Braised pork is a typical meat product that is cooked at a high temperature (usually $100^{\circ} \mathrm{C}$ ) for at least 150 min. During such a long-time cooking, heavy lipid and protein oxidation may occur, which further has a great impact on meat texture, flavor and decreased protein digestion $[9,10,11]$. Li et al. [12] used a plane induction cooker to optimize the process and found that the texture and sensory scores of braised pork were the highest after pre-frying combined with stewing for $150 \mathrm{~min}$. However, there are some difficulties in applying such a plane induction cooker to a large-scale processing practice of braised pork in meat industry because of lowenergy efficiency. The concave induction cooker could be a good alternative. Given concave induction cooker has higher heating efficiency compared to plane induction cooker, it may reduce the protein and lipid oxidation in meat and improve meat quality by shortening the cooking time.

The purposes of this study were to evaluate the feasibility of concave induction cooking to improve the heating efficiency and meat quality attributes of braised pork compared with the plane induction cooking.

Copyright (c) 2021, Da et al.This is an open access article distributed under the terms of the Creative Commons Attribution 4.0 International License (http://creativecommons.org/ licenses/by/4.0/), allowing third parties to copy and redistribute the material in any medium or format and to remix, transform, and build upon the material for any purpose, even commercially, provided the original work is properly cited and states its license. 


\section{Objects and methods}

\section{Sample preparation}

Pork belly samples (the upper part of the abdomen of pigs of $110 \mathrm{~kg}$ slaughter weight at 6 months old) containing $2.29 \%$ of lipid (determined by the Soxhlet method) and $72.72 \%$ of moisture (determined by the direct drying method) were obtained at $24 \mathrm{~h}$ postmortem from a commercial company (Sushi, Jiangsu, China). Pork belly samples were collected from eight Duroc $\times$ Landrace $\times$ Yorkshire crossbred pigs that had similar feeding conditions and body weights. The belly was cut into 4 $\mathrm{cm}$ strips. The strips were bleached in boiling water for $5 \mathrm{~min}$ to remove blood residues and make the meat samples easy to cut. Then the strips were cut into smaller cubes $(3 \times 3 \times 5 \mathrm{~cm})$.

\section{Cooking}

The cubes (about $1.5 \mathrm{~kg}, 28-32$ pieces) were stir fried for $20 \mathrm{~min}$ with soybean oil ( $20 \mathrm{~g}$ per $\mathrm{kg}$ meat) in a plane induction cooker (Jiuyang, Shandong, China) or a concave induction cooker (Kerun, Shandong, China) at a power of $1.4 \mathrm{~kW}$. Then the oil was removed, and water, wine (40 g per $\mathrm{kg}$ meat), vinegar (4 g per $\mathrm{kg}$ meat), soy sauce (20 g per kg meat), sugar (40 g per kg meat) and salt (5 g per $\mathrm{kg}$ meat) were added and cooked at $2 \mathrm{~kW}$ for $60 \mathrm{~min}, 90 \mathrm{~min}, 120 \mathrm{~min}$ or $150 \mathrm{~min}$, respectively. The ratio of water to meat depended on the cooking time, including $0.7,1.2,1.4$ and 1.9 for plane induction cooker at $60 \mathrm{~min}, 90 \mathrm{~min}, 120 \mathrm{~min}$ or $150 \mathrm{~min}$, respectively, and 1.5, $1.9,2.7$ and 3.65 for concave induction cooker at $60 \mathrm{~min}$, $90 \mathrm{~min}, 120 \mathrm{~min}$ or $150 \mathrm{~min}$, respectively. The water was added for two times to the concave induction cooker for each group but once to the plane induction cooker. For the former, the amount of added water at the first time was same as that of the plane induction cooker and the remainder water was added when the water in the cooker was completely evaporated. There were 8 groups and each group had 8 repeats. Induction cookers were shown in Figure 1. The ingredients and fatty acid composition of soybean oil were shown in Tables land 2.
Table 1. Information of ingredients

\begin{tabular}{|c|c|c|}
\hline $\begin{array}{l}\text { Ingredi- } \\
\text { ents }\end{array}$ & Brand & Raw material \\
\hline $\begin{array}{l}\text { Soybean } \\
\text { oil }\end{array}$ & $\begin{array}{l}\text { Jin- } \\
\text { longyu }\end{array}$ & $\begin{array}{l}\text { soybean oil }(49 \%) \text {, canola oil }(21 \%) \text {, sunflower } \\
\text { seed oil }(14 \%) \text {, corn oil }(9 \%) \text {, peanut oil }(3 \%) \text {, } \\
\text { rice oil }(3 \%) \text {, sesame oil }(0.6 \%) \text {, sesame oil } \\
(0.4 \%)\end{array}$ \\
\hline Wine & Shuita & $\begin{array}{l}\text { drinking water, yellow rice wine, white wine, } \\
\text { monosodium glutamate, edible salt, onion } \\
\text { juice, ginger juice, caramel color }\end{array}$ \\
\hline Vinegar & Shuita & $\begin{array}{l}\text { drinking water, sorghum, bran, barley, peas, } \\
\text { edible salt, spices, caramel color, sodium } \\
\text { benzoate }\end{array}$ \\
\hline $\begin{array}{l}\text { Soy } \\
\text { sauce }\end{array}$ & Haitian & $\begin{array}{l}\text { water, soy beans, edible salt, caramel color, } \\
\text { wheat, granulated sugar, sodium glutamate, } \\
\text { mushroom }\end{array}$ \\
\hline Sugar & Suguo & white crystal sugar \\
\hline Salt & Huaiyan & $\begin{array}{l}\text { refined salt, potassium iodate, ammonium } \\
\text { ferric citrate }\end{array}$ \\
\hline
\end{tabular}

Table 2. Fatty acid composition (mg/g oil) of soy bean oil

\begin{tabular}{|c|c|}
\hline Fatty acid & Content \\
\hline C16:0 & $9.51 \pm 6.84$ \\
\hline C18:0 & $3.41 \pm 2.45$ \\
\hline SFA & $12.93 \pm 9.28$ \\
\hline C18:1n9c & $33.51 \pm 24.12$ \\
\hline MUFA & $33.51 \pm 24.12$ \\
\hline C18:2n6c & $99.4 \pm 72.6$ \\
\hline C18:3n3 & $5.99 \pm 4.34$ \\
\hline PUFA & $105.39 \pm 76.93$ \\
\hline
\end{tabular}

\section{Cooking performance evaluation}

The cubes (about $1.5 \mathrm{~kg}$ ) were cooked in water $(2.7 \mathrm{~kg})$ in a plane induction cooker $(2 \mathrm{~kW})$ or a concave induction cooker $(2 \mathrm{~kW})$ until all water was lost. The center temperature of meat cubes was tracked by a thermal probe (Yuwese, Shenzhen, China) and time to reach the cooking endpoint (when water was lost) was recorded. The cooking procedures were repeated for eight times $(\mathrm{n}=8$ each).

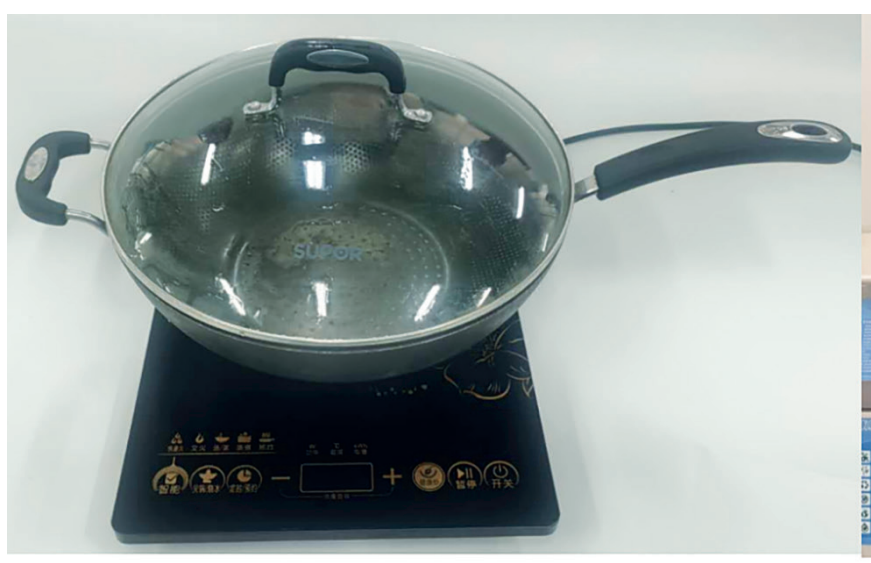

A

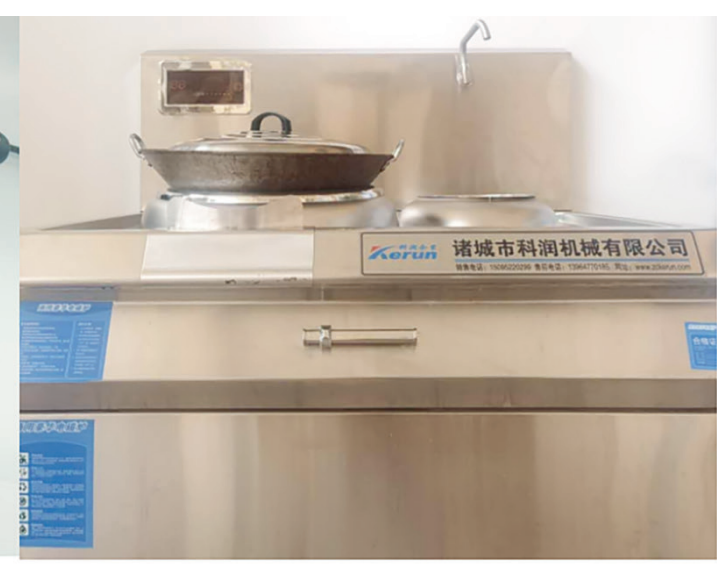

B

Figure 1. Pictures of plane and concave induction cooker used: A - plane induction cooking; B - concave induction cooking 


\section{Texture profile analysis}

The samples were cut into $1 \mathrm{~cm} \times 1 \mathrm{~cm} \times 1 \mathrm{~cm}$ cubes. Texture of lean meat (muscle tissue) portions of braised pork cubes was determined by a TA.XT plus texture analyzer (XT Plus, Stable Micro systems Ltd, Godalming, UK) as previously described by Li et al. [12]. The parameters were set as follows: probe, $50 \mathrm{~mm}$ stainless cylinder; pre-test speed, $2 \mathrm{~mm} / \mathrm{s}$; test speed, $1 \mathrm{~mm} / \mathrm{s}$; a compression rate, $50 \%$; post-test speed, $5 \mathrm{~mm} / \mathrm{s}$; trigger force, $5 \mathrm{~g}$; testing interval time, $5 \mathrm{~s}$. Hardness, springiness, cohesiveness and chewiness were recorded. The results were analyzed with the Texture Expert Exceed software (Stable Micro Systems Ltd). Eight replications were prepared for each treatment.

\section{Fatty acid profiling}

Lipid was extracted from the lean parts of braised pork as previously described by $\mathrm{Li}$ et al. [12]. Briefly, the lean $(6 \mathrm{~g})$ was mixed with chloroform/methanol 2:1 (v/v) solution $(40 \mathrm{~mL})$. Then the solution was filtered. The filtrate was mixed with $0.9 \% \mathrm{NaCl}(8 \mathrm{~mL})$ and centrifuged at $3000 \mathrm{rpm}$ for $15 \mathrm{~min}$. The organic phase (the lower part) was dried in a rotary evaporator at $44^{\circ} \mathrm{C}$ water bath and the remainder was lipid. The lipid was saponified in a sodium hydroxide methanol solution and methylated in a $14 \%$ boron trifluoride methanol solution as described by Chen et al. [13]. The mixtures were analyzed by gas chromatography (GC2010 plus, Shimadzu, Kyoto, Japan). The volatile compounds were separated in a SP2560 column $(100 \mathrm{~mm} \times 0.25 \mathrm{~mm} \times 0.25 \mathrm{~mm}$, Supelco, Bellefonte, PA). The chromatography conditions were set as follows: injection volume, $1 \mu \mathrm{L}$; inlet temperature, $270^{\circ} \mathrm{C}$; FID temperature, $280^{\circ} \mathrm{C}$. A temperature program was set as follows: $100^{\circ} \mathrm{C}$ for $13 \mathrm{~min} \rightarrow$ an increase to $180^{\circ} \mathrm{C}$ with a rate of $10^{\circ} \mathrm{C} / \mathrm{min} \rightarrow 100^{\circ} \mathrm{C}$ for $6 \mathrm{~min} \rightarrow$ an increase to $200^{\circ} \mathrm{C}$ at a rate of $1^{\circ} \mathrm{C} / \mathrm{min} \rightarrow 200^{\circ} \mathrm{C}$ for $20 \mathrm{~min} \rightarrow$ an increase to $230^{\circ} \mathrm{C}$ at a rate of $4{ }^{\circ} \mathrm{C} / \mathrm{min} \rightarrow 230^{\circ} \mathrm{C}$ for $10.5 \mathrm{~min}$. The carrier gas was highly pure $\mathrm{N}_{2}$ with a flow rate of $1 \mathrm{~mL} / \mathrm{min}$, and the split ratio was 100:1. A mixed standard containing 37 fatty acids (CEM 47885, Supelco, Bellefonte, PA) was applied as external standard. Fatty acids in samples were quantified by an internal standard (methyl nonadenoate, C19:0). Atherogenicity index (AI) and thrombogenicity index (TI) were calculated according to the previous study [14]:

$$
\mathrm{AI}=\frac{C 12: 0+C 14: 0+C 16: 0}{\mathrm{n}-3 \mathrm{PUFA}+\mathrm{n}-6 \mathrm{PUFA}+\text { MUFA }}
$$

$\mathrm{TI}=\frac{C 14: 0+C 16: 0+\mathrm{Cl}: 0}{0.5 \times \mathrm{MUFA}+0.5 \times \mathrm{n}-6 \mathrm{PUFA}+3 \times \mathrm{n}-3 \mathrm{PUFA}+\mathrm{n}-3 \mathrm{PUFA} / \mathrm{n}-6 \mathrm{PUFA}}$

\section{Lipid oxidation}

Lipid oxidation was determined according to the method of Soladoye et al. [15] with minor modifications. Briefly, meat samples $(5 \mathrm{~g})$ were homogenized for $30 \mathrm{~s}$ in trichloroacetic acid (TCA, 7.5\%, $25 \mathrm{~mL}$ ). The homogenate was centrifuged at $12000 \mathrm{~g}$ for $5 \mathrm{~min}$ to remove the protein and other materials in meat. Two milliliters of the super- natant were taken and mixed with $2 \mathrm{~mL}$ of thiobarbituric acid $(0.02 \mathrm{M})$. The mixture was well vortexed and heated at $95^{\circ} \mathrm{C}$ (TW 20, Julabo Labortechnik GmbH, Germany) for $30 \mathrm{~min}$. The absorbance was measured at $532 \mathrm{~nm}$ and the concentration of thiobarbituric acid reactive substances (TBARS) was calculated from a standard curve (1,1,3,3-tetra ethoxypropane, $\left.0-1.5 \mu \mathrm{g} / \mathrm{mL}, \mathrm{R}^{2}>0.999\right)$. The results were expressed in mg malonaldehyde (MDA) per $\mathrm{kg}$ of meat samples.

\section{Protein carbonyl groups}

Meat samples (1 g) were homogenized for $60 \mathrm{~s}$ in $5 \mathrm{~mL}$ of buffer solution $\left[10 \mathrm{mM} \mathrm{K} \mathrm{HPO}_{4}, 0.1 \mathrm{M} \mathrm{NaCl}, 2 \mathrm{mM}\right.$ $\mathrm{MgCl}_{2}, 1 \mathrm{mM}$ ethylene bis (oxyethylenenitrilo) tetraacetic acid (EGTA)] at pH 7.0 and then centrifuged at $10000 \mathrm{~g}$ for $20 \mathrm{~min}$. The supernatants were removed, and pellets were collected. After two repeated cycles of homogenization and centrifugation, the resulting pellets were suspended in $5 \mathrm{~mL}$ of $0.1 \mathrm{M} \mathrm{NaCl}$. The suspended samples were centrifuged again at $10000 \mathrm{~g}$ for $20 \mathrm{~min}$. The pellets were re-suspended in $5 \mathrm{~mL}$ of $0.6 \mathrm{M} \mathrm{NaCl}$ and filtered through four layers of gauze. The filtrate was collected as protein solution.

The protein concentration was determined using a bicinchoninic acid protein assay kit (Thermo Scientific, Waltham, MA) with bovine serum albumin as the standard. The carbonyl content was determined according to Oliver et al. [16] with minor modifications. Briefly, $1 \mathrm{~mL}$ protein solution was mixed with $2 \mathrm{M} \mathrm{HCl}$ (control) or $10 \mathrm{mM}$ 2,4-dinitrophenylhydrazine (DNPH) in $2 \mathrm{M} \mathrm{HCl}$ and incubated in dark at room temperature for $1 \mathrm{~h}$. Then $1 \mathrm{~mL}$ of $20 \%$ TCA solution was added and the mixture was centrifuged at $8000 \mathrm{~g}$ for $10 \mathrm{~min}$. The pellets were washed three times with $1 \mathrm{~mL}$ ethanol-ethyl acetate $(1: 1, \mathrm{v} / \mathrm{v})$ and then suspended in $3 \mathrm{~mL}$ of $6 \mathrm{M}$ guanidine $\mathrm{HCl}$ at $37^{\circ} \mathrm{C}$ for $30 \mathrm{~min}$. The suspension was centrifuged at $8000 \mathrm{~g}$ for $5 \mathrm{~min}$. The carbonyl concentration was calculated using the absorption of $21000 \mathrm{M}^{-1} \mathrm{~cm}^{-1}$ at $370 \mathrm{~nm}$. The absorbance is determined using a spectrophotometer (Molecular Devices, California, USA).

\section{Protein thiol group}

Protein thiol content was determined according to Lund et al. [17]. Briefly, meat samples $(1 \mathrm{~g})$ were homogenized for $30 \mathrm{~s}$ in $25 \mathrm{~mL}$ of $5 \%$ sodium dodecylsulphate (SDS) in $0.10 \mathrm{M}$ Tris buffer ( $\mathrm{pH} 8.0$ ) and then heated in a $90^{\circ} \mathrm{C}$ water bath for $30 \mathrm{~min}$. Then the solution was cooled and centrifuged at $1200 \mathrm{~g}$ for $20 \mathrm{~min}$. The supernatants were filtered and protein concentration in the filtrate was determined using a BCA protein assay kit (Thermo Scientific, Waltham, MA). The filtrate $(0.5 \mathrm{~mL})$ was mixed with $2 \mathrm{~mL} 0.10 \mathrm{M}$ Tris buffer (pH 8.0) and $0.5 \mathrm{~mL} 10 \mathrm{mM}$ 5,5'-dithiobis (2-nitrobenzoic acid) (DTNB) in $0.10 \mathrm{M}$ Tris buffer ( $\mathrm{pH} 8.0)$. Absorbance at $412 \mathrm{~nm}$ was measured after reacting for $30 \mathrm{~min}$ against a reference solution of $0.50 \mathrm{~mL}$ 5\% SDS and $2.50 \mathrm{~mL} \mathrm{0.10} \mathrm{M} \mathrm{Tris} \mathrm{buffer} \mathrm{(pH} \mathrm{8.0).} \mathrm{The} \mathrm{thi-}$ 
ol concentration was calculated using the absorption of $13600 \mathrm{M}^{-1} \mathrm{~cm}^{-1}$.

\section{E-nose measurement}

Meat samples $(1 \mathrm{~g})$ were transferred to $20 \mathrm{~mL}$ headspace bottles and immediately sealed. Samples were preheated in a $70^{\circ} \mathrm{C}$ water bath (TW 20, Julabo Labortechnik GmbH, Germany) for $10 \mathrm{~min}$. The headspace bottle was inserted by a syringe needle with a hollow tube and headspace gas was sucked out. The headspace gas entered into the E-nose through a water filtration membrane, then the same needle was inserted into the same headspace bottle and the air was sucked to replenish volatile gas. The data collection time was $120 \mathrm{~s}$, and the clean time was $100 \mathrm{~s}$ [18]. The performance of the PEN3 portable E-nose sensors (Win Muster Airsense Analytics Inc, Schwerin, Germany) was shown in Table 3.

Table 3. Performance description of PEN3 portable electronic nose sensors

\begin{tabular}{|r|l|}
\hline $\begin{array}{r}\text { Sensor name } \\
\text { W1C }\end{array}$ & \multicolumn{1}{|c|}{ Performance description } \\
\hline W5S & Aromatic compounds \\
\hline W3C & Ammonia, aromatic compounds \\
\hline W6S & hydrocarbons \\
\hline W5C & Alkanes and aromatics \\
\hline W1S & Methane, broad range of compounds \\
\hline W1W & Sulfur compounds, pyrazines and terpenes \\
\hline W2S & Broad range, alcohols, aromatic compounds \\
\hline W2W & Aromatics and organic sulfur compounds \\
\hline W3S & Methane and aliphatic compounds \\
\hline
\end{tabular}

\section{GC-MS}

Volatile compounds were identified by a Thermo GCMS system comprising of a TRACE GC ULTRA gas chromatograph and a DSQ II mass selective detector (Thermo Scientific, Waltham, MA). Briefly, lean samples (5 g) were taken and transferred into a $20 \mathrm{~mL}$ headspace bottle and then immediately sealed. An aged 50/30 $\mu$ m CAR/PDMS/ DVB solid-phase microextraction fiber (Supelco, Bellefonte, PA) was inserted into the $20 \mathrm{~mL}$ headspace bottle. The volatile compounds in the headspace bottle were collected at $60^{\circ} \mathrm{C}$ for $30 \mathrm{~min}$ with the fiber, and the fiber was injected into the GC inlet. The fiber was desorbed at $250^{\circ} \mathrm{C}$ for $3 \mathrm{~min}$.

Gas chromatography was performed with an inlet temperature of $250^{\circ} \mathrm{C}$ and a DB-WAX capillary fiber (30 $\mathrm{m} \times 0.25 \mathrm{~mm} \times 0.25 \mu \mathrm{m}$, Agilent, Santa Clara, CA) was used for separation. The carrier gas was helium, and the flow rate was set at $0.8 \mathrm{~mL} / \mathrm{min}$. The gas chromatographic temperature conditions were programmed as follows: the furnace temperature was maintained at $40^{\circ} \mathrm{C}$ for $3 \mathrm{~min}$, then increased to $90^{\circ} \mathrm{C}$ at a rate of $5^{\circ} \mathrm{C} / \mathrm{min}$, further to $230^{\circ} \mathrm{C}$ at a rate of $10^{\circ} \mathrm{C} / \mathrm{min}$ and kept at $230^{\circ} \mathrm{C}$ for $7 \mathrm{~min}$.

Mass spectrometry was done under the conditions of EI source as ion source with ionization mode of EI + and electron energy of $70 \mathrm{eV}$. The ion source temperature was $200^{\circ} \mathrm{C}$, and interface temperature was $250^{\circ} \mathrm{C}$.
The retention time (RI) of the volatile compounds was converted to a linear retention index by n-Alkanes (C7C26). The retention indices were compared to those in the NIST database (https://webbook.nist.gov/chemistry/ name-ser/) and the matching factor was over 800 . The retention index is calculated as described by Xu et al. [19] as follows:

$$
\mathrm{RI}=\left[\frac{R t(x)-R t(n)}{R t(n+1)-R t(n)}+n\right] \times 100
$$

Where $R t(x), R t(n)$ and $R t(n+1)$ are the retention times of the volatile compounds to be tested, and the normal paraffin containing $\mathrm{n}$ carbon atoms and the $n$-alkane of $n+1$ carbon atoms, respectively. Cyclohexanone was used as the internal standard to conduct semi-quantitative analysis by comparing the peak area of volatile compounds with the peak area of the internal standard.

\section{Sensory evaluation}

Sensory evaluation was performed according to the method described by Wang et al. [20] with some modifications. A professional panel of 12 (6 males and 6 females) members assessed the samples. Samples were evaluated for odor, color, texture and taste using the 9-point hedonic scale $(1=$ very unpleasant and $9=$ very pleasant $)$.

\section{Statistical analysis}

Cooking performance was evaluated by t-test in which cooking method was set as the independent. Eight repeats were performed. For texture attributes, fatty acids, lipid and protein oxidation, volatile compounds, and sensory test, factorial analysis of variance (ANOVA) with a mixed model was applied, in which cooking method, cooking time and their crosses were set as fixed effects, and sampling batch was set as a random effect. Least-squares means were compared by the Tukey's t test. The above statistical analyses were done by the SAS software (SAS Institute Inc, Cary, CA). E-nose data were analyzed by principal component analysis to discriminate the measured samples using the Winmuster software (Win Muster Airsense Analytics Inc, Schwerin, Germany). The significance level was set at 0.05 .

\section{Results and discussion}

\section{Performance evaluation and texture profile analysis}

Compared with plane induction cooking, concave induction cooking had higher energy efficiency with shorter cooking time and lower energy consumption to achieve the same setting endpoint where the added water was completely evaporated (125 min vs. $66 \mathrm{~min}$ for cooking time; $4.38 \mathrm{kw} \cdot \mathrm{h}$ vs. $2.2 \mathrm{kw} \cdot \mathrm{h}$ for energy consumption, $\mathrm{P}<0.05$, Figure 2, A and B). The center temperatures of the meat samples near the center of the cookers were higher at $10 \mathrm{~min}, 20 \mathrm{~min}$ and $30 \mathrm{~min}$ in the concave induction cooker than those in the plane induction cooker $(\mathrm{P}<0.05$, Figure 2, C). This could be due to the fact that 


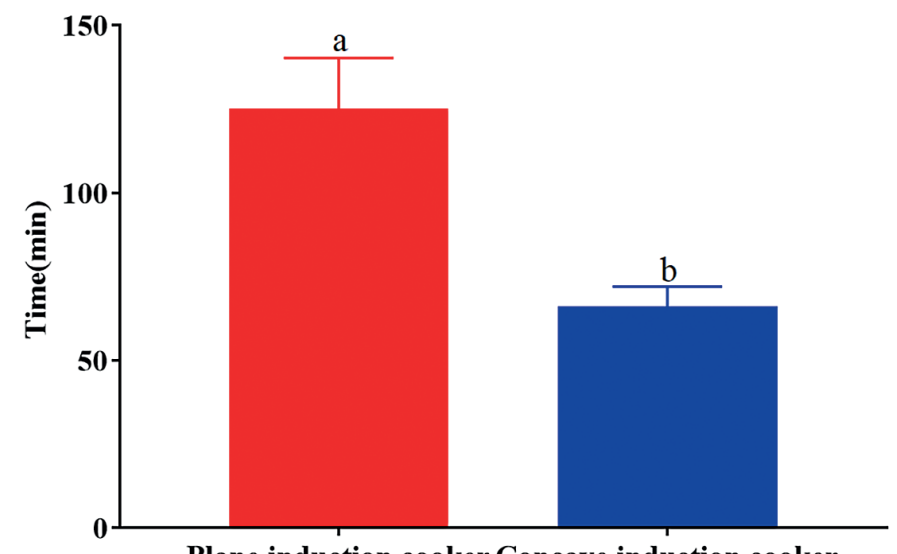

Plane induction cooker Concave induction cooker A

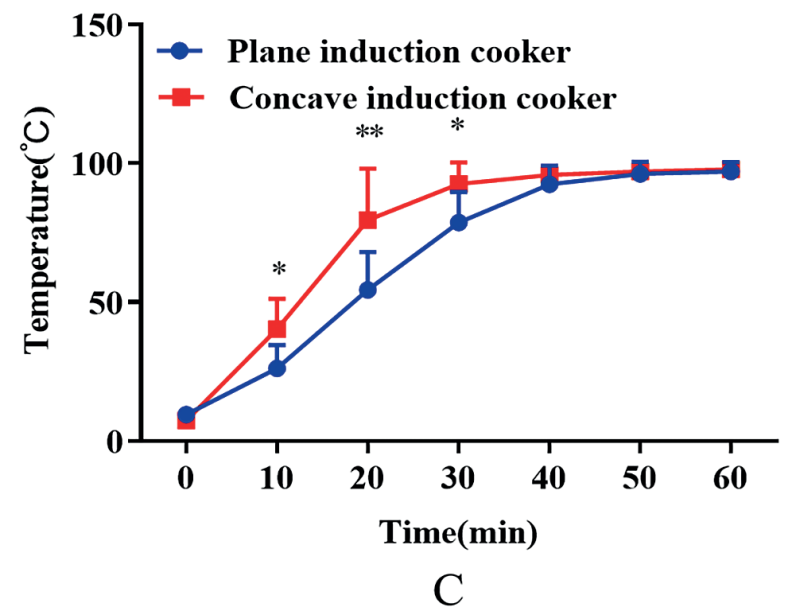

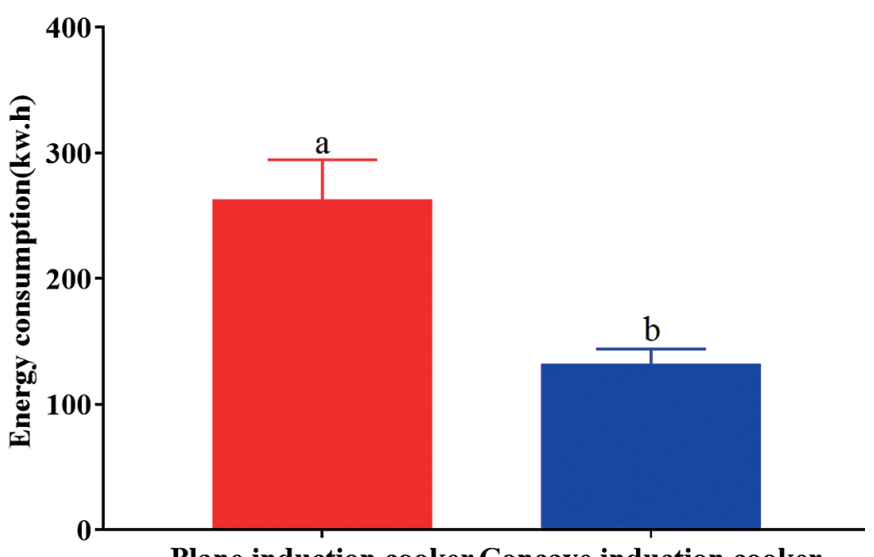

Plane induction cooker Concave induction cooker $\mathrm{B}$

a, b means differed significantly among cooking time points $(\mathrm{P}<0.05) .{ }^{*}$, significant differences existed between concave induction cooking and plane induction cooking at a certain time point $(\mathrm{P}<0.05)$.

Figure 2. Performance of two cooking methods: A - time to reach the end point that added water was lost; $\mathrm{B}$ - energy consumption to reach the end point; $\mathrm{C}$ - the center temperature of meat

concave induction cooker has a variable turn pitch coil (concave coil) making it have larger heating area and better heating performance [21]. Therefore, it is feasible to improve the texture and flavor of braised pork by concave induction cooking for shorter time than by plane induction cooking.

Texture is an important aspect for the sensory acceptance of meat. The main factors affecting meat texture are cooking temperature and time. Jiang et al. [22] observed that hardness and chewiness of bighead carp (aristichthys nobilis) muscle showed two peaks during heating, but springiness, adhesiveness, and cohesiveness declined.

As cooking time increased, the hardness, chewiness, springiness and cohesiveness of braised pork decreased greatly $(\mathrm{P}<0.05$, Figure 3$)$, which gave stronger responses to concave induction cooking than to plane induction cooking. Generally, concave induction cooking resulted in much lower hardness and chewiness, at $60 \mathrm{~min}, 90 \mathrm{~min}$ and $120 \mathrm{~min}$, and lower springiness and cohesiveness at $120 \mathrm{~min}$ and $150 \mathrm{~min}$, compared with plane induction cooking $(\mathrm{P}<0.05)$. In a previous study, we observed that braised pork cooked in a plane induction cooker for $150 \mathrm{~min}$ had the best texture [12]. Consumers usually prefer tender braised pork. In the present study, hardness of braised pork cooked for $60 \mathrm{~min}$ in the concave induction cooker reached the values of those cooked for $120 \mathrm{~min}$ in the plane induction cooker, but the latter had higher chewiness, springiness and cohesiveness $(\mathrm{P}<0.05)$. This indicates that concave induction cooking may improve the texture of braised pork with shorter cooking time. Concave induction cooking for $60 \mathrm{~min}$ may be considered as a better cooking method for braised pork among the applied cooking parameters.

The decrease in hardness is caused by the fracture of myofibrillar structure. The lower hardness of the braised pork prepared by concave induction cooking could be because the temperature of concave induction cooker at early cooking time is significantly higher than that of the plane induction cooker, resulting in greater damage to myofibrillar structure. Similar results showed that the hardness, springiness and chewiness of Volutharpaampullacealperryi (commonly known as fake abalone) would be more obviously reduced by high temperature [23].

\section{Fatty acid profile}

Pork lean fractions contain different types of fatty acids. In raw and cooked lean samples of braised pork, the fatty acids predominantly comprise of myristic acid, palmitic acid, palmitoleic acid, stearic acid, oleic acid and linoleic acid (Table 4). Cooking method showed a certain 

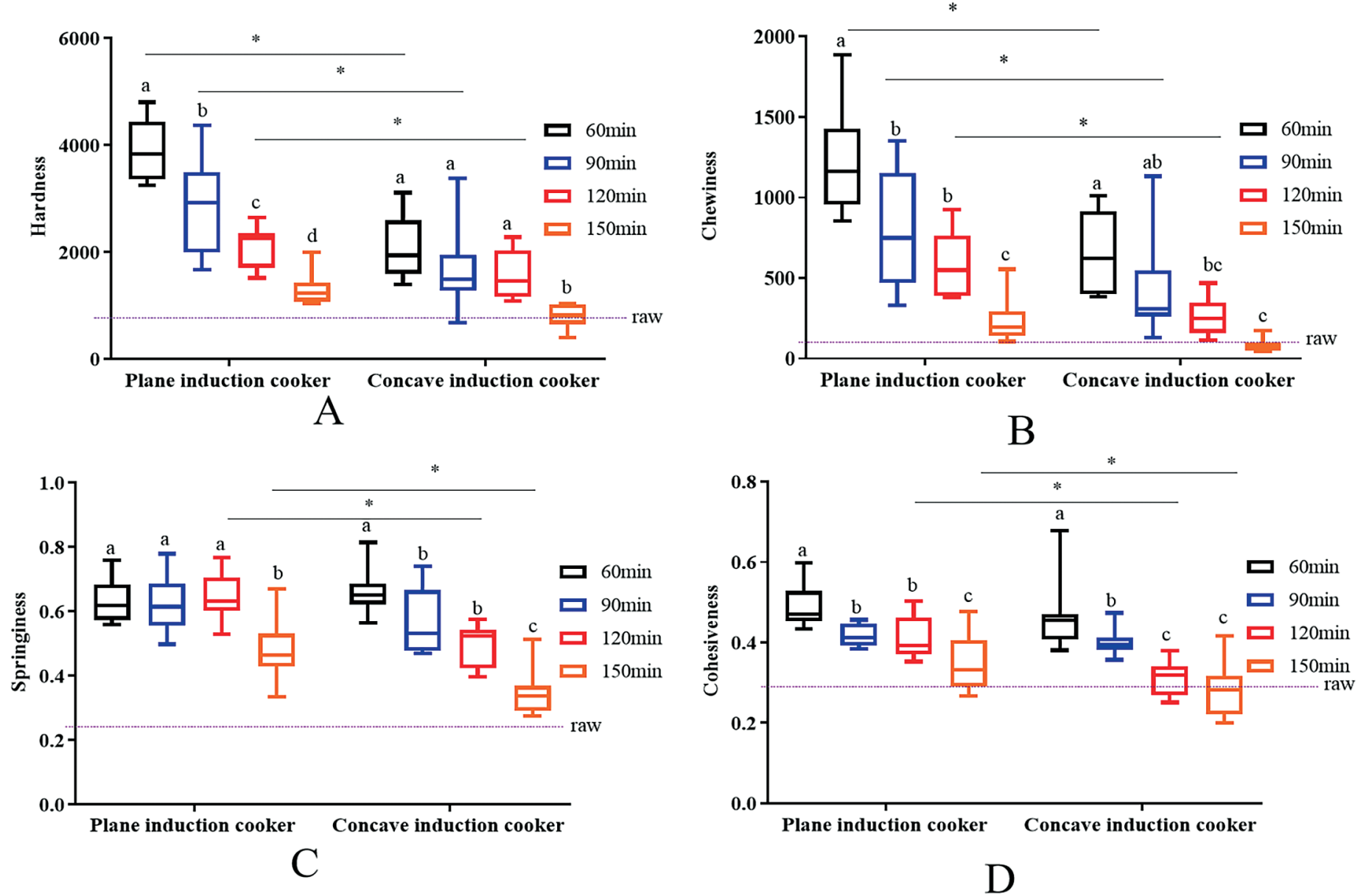

a, b, c means differed significantly among cooking time points $(\mathrm{P}<0.05) .{ }^{*}$, significant differences existed between concave induction cooking and plane induction cooking at a certain time point $(\mathrm{P}<0.05)$.

Figure 3. Texture profile of braised pork: A - Hardness; B - Springiness; C - Chewiness; D - Cohesiveness

impact on medium chain fatty acids (MCT), saturated fatty acids (SFA), unsaturated fatty acids (UFA), monounsaturated fatty acids (MUFA), polyunsaturated fatty acids (PUFA) and TI value $(\mathrm{P}<0.05$, Figure 4$)$ but did not affect the PUFA/SFA ratio and AI value $(\mathrm{P}>0.05)$. At $150 \mathrm{~min}$ of cooking, concave induction cooking increased the contents of MCT, SFA, UFA, MUFA and PUFA $(\mathrm{P}<0.05)$. Cooking time showed a greater effect on the above variables. MCT content and PUFA/SFA ratio increased with cooking time in the plane induction cooker $(\mathrm{P}<0.05)$. In contrast, the AI values decreased with cooking time. However, in concave induction cooker, the contents of MCT, SFA, UFA, MUFA, PUFA and TI value increased with cooking time $(\mathrm{P}<0.05)$. In addition, significant differences were observed between the two cooking methods in MCT, SFA, UFA, MUFA and PUFA contents at 150 min of cooking time $(\mathrm{P}<0.05$, Figure 4, A-E). MCT are healthy fatty acids, which may inhibit fat deposition by enhancing the thermogenesis and oxidation of human body. In addition, MCT have a certain therapeutic effect on type 2 diabetes [24]. MUFA could reduce the risk of cardiovascular disease and inflammation-related diseases [25]. The increase in saturated fatty acids, including MCT, may be due to the oxidation of some unsaturated fatty acids to saturated fatty acids after prolonged cooking. Several studies suggest that PUFA are structural lipids that are released during cooking [26,27].
Significant differences were observed between the two cooking methods in UFA at 150 min of cooking time $(\mathrm{P}<0.05$, Figure $4, \mathrm{C})$, but no significant difference existed at other time points $(\mathrm{P}>0.05)$. The greatest changes in SFA content occurred for C14:0 and C16:0. Significant differences were observed between the two cooking methods in C14:0 and C16:0 contents at $150 \mathrm{~min}$ of cooking time $(\mathrm{P}<0.05$, Table 4). Higher C14:0 and C16:0 may cause higher concentrations of total and LDL cholesterol in plasma $[28,29]$.

The value of PUFA/SFA of concave induction cooking at $60 \mathrm{~min}$ was greater than 0.40 that is recommended to prevent cholesterol elevation and reduce the risk of coronary heart disease [30]. The TI value of concave induction cooked samples for $60 \mathrm{~min}$ was lower than that of plane induction cooked samples at $60 \mathrm{~min}(\mathrm{P}<0.05$, Figure 4, $\mathrm{F}-\mathrm{H})$. AI is a good indicator for assessing the risk of atherosclerosis, while TI is an indicator for assessing the possibility of platelet aggregation [31]. In this case, concave induction cooking for 60 min may produce healthier braised pork compared with plane induction cooking. Several fatty acids could not be detected in a part of samples, which may be due to their low abundance in pork [32]. In addition, the $\mathbf{n}-6 / \mathbf{n}-3$ ratio was higher than the values of 1 to 4 as recommended by Simopoulos et al. [33]. This is because the abundance of n-3 fatty acids is low in pork $[34,35]$. 


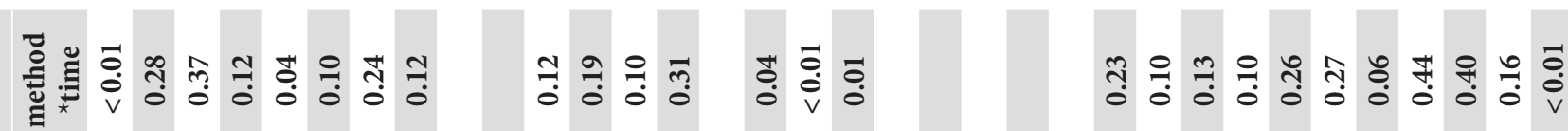

产 节

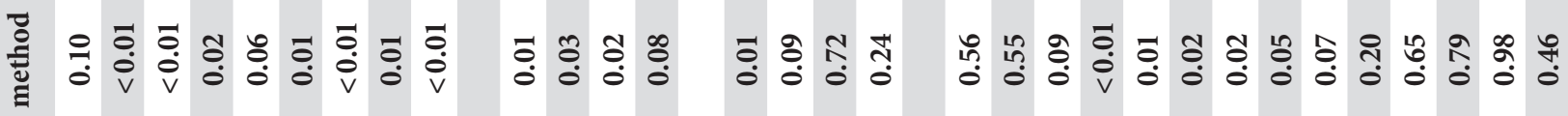

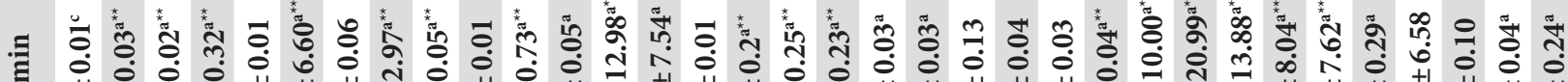

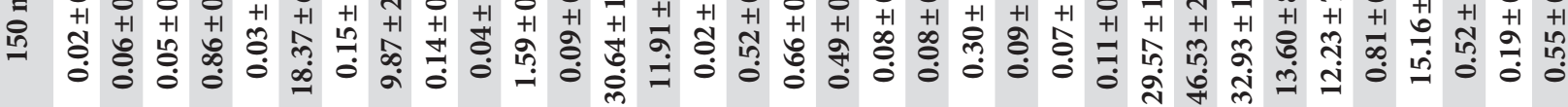

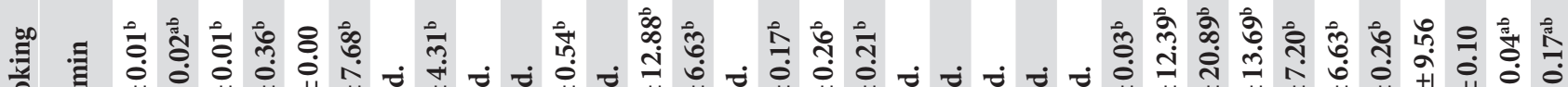

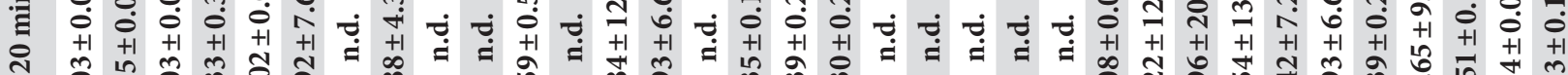

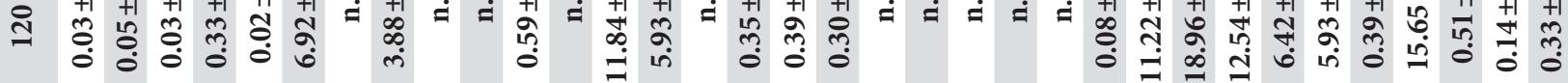

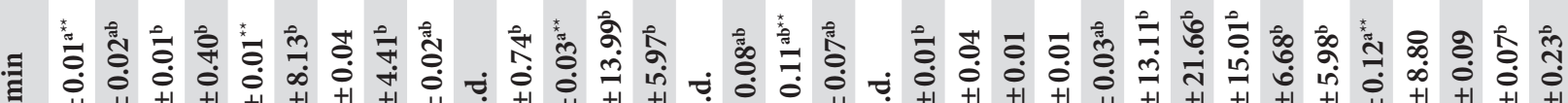

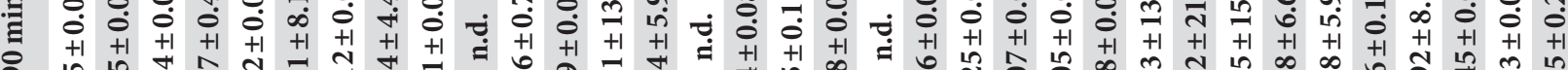

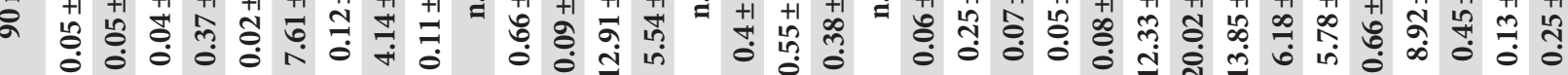

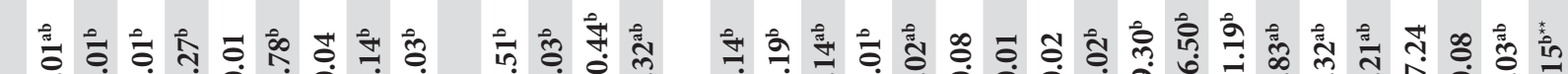

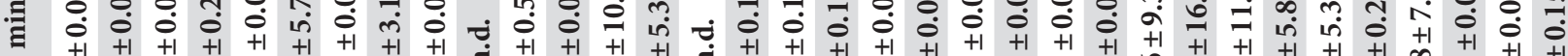

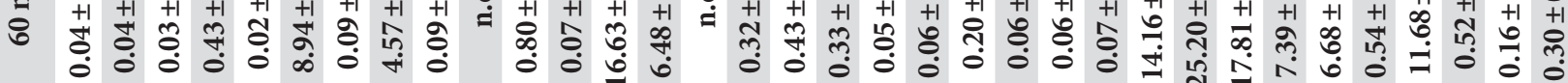

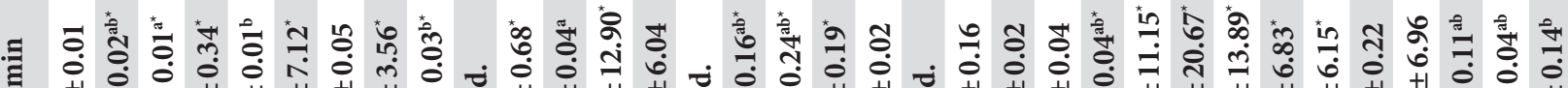

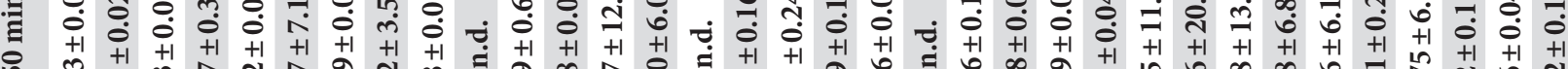

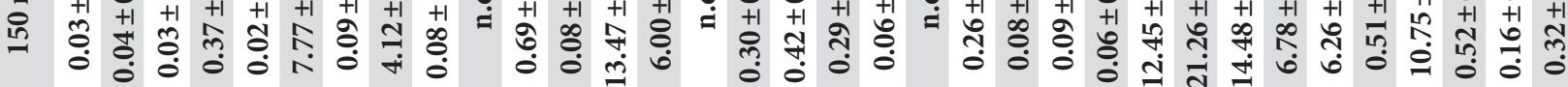

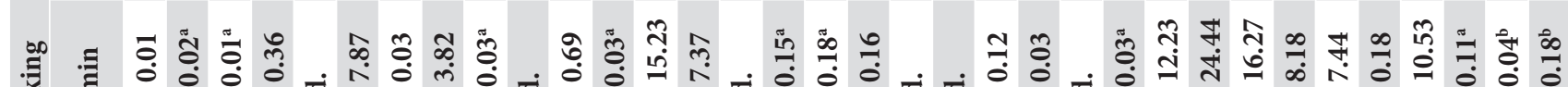

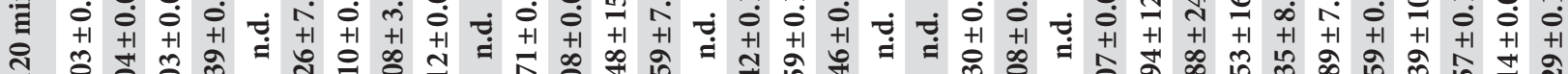

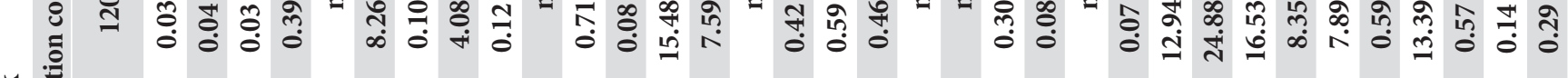

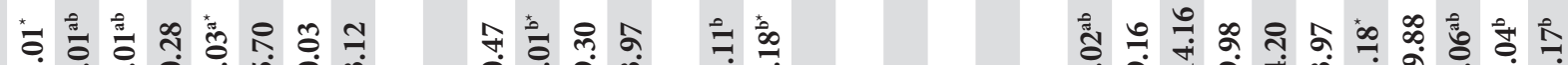

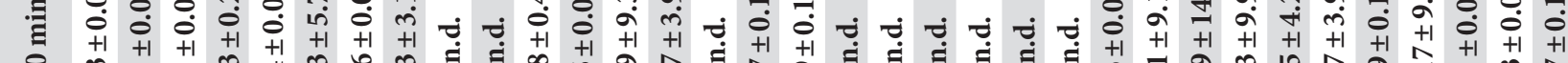

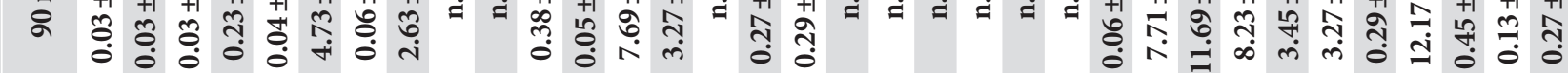

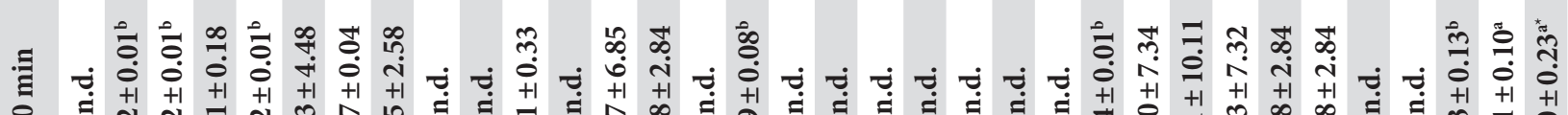

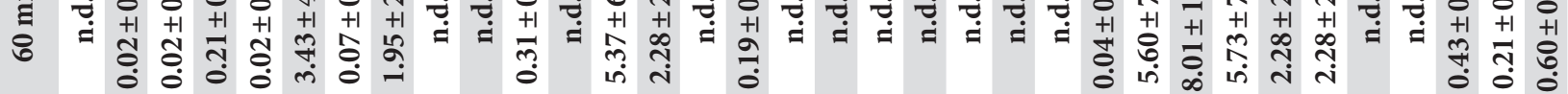

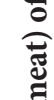

$\stackrel{8}{900}$

$$
\text { o in os in } 4 \text { is } 00
$$

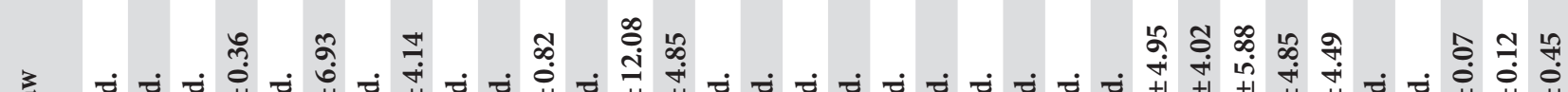

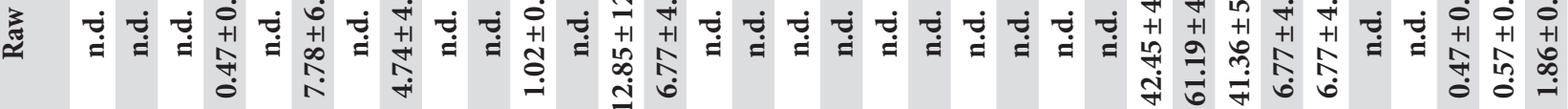
:

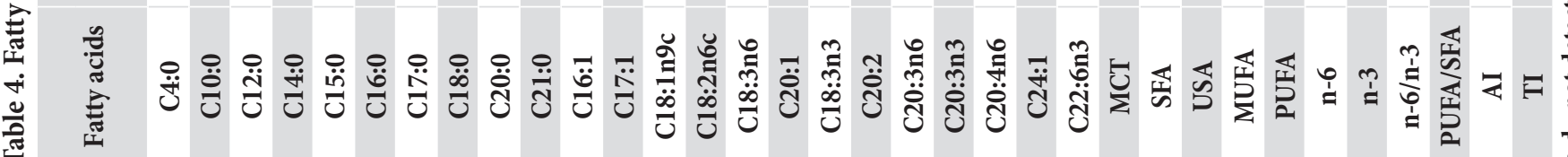




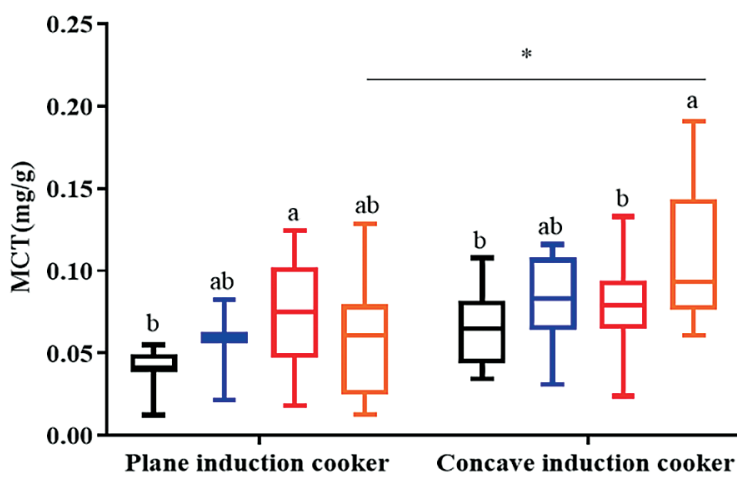

A

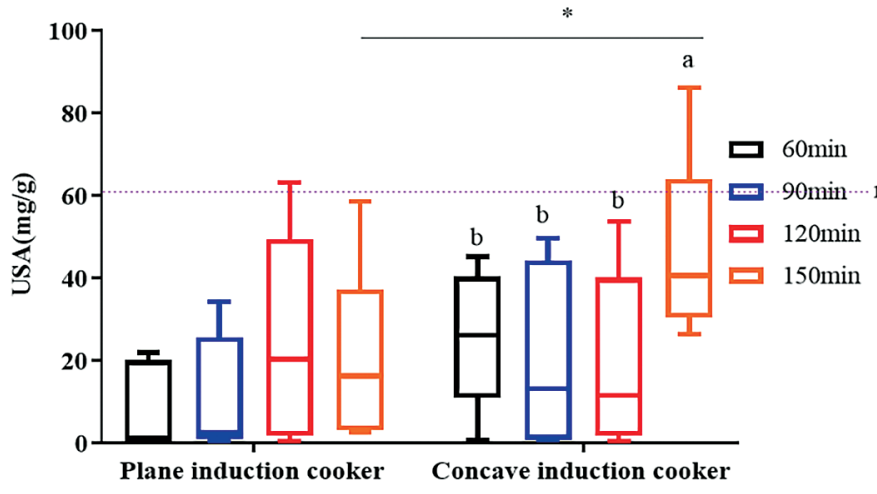

$\mathrm{C}$

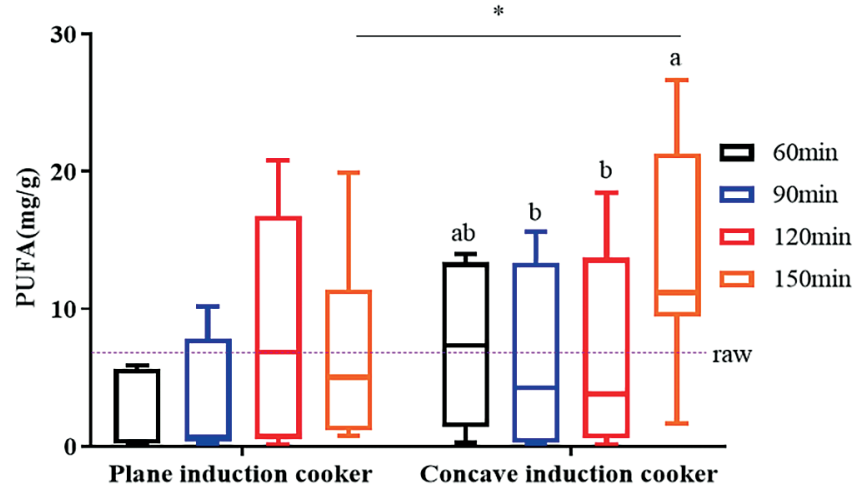

$\mathrm{E}$

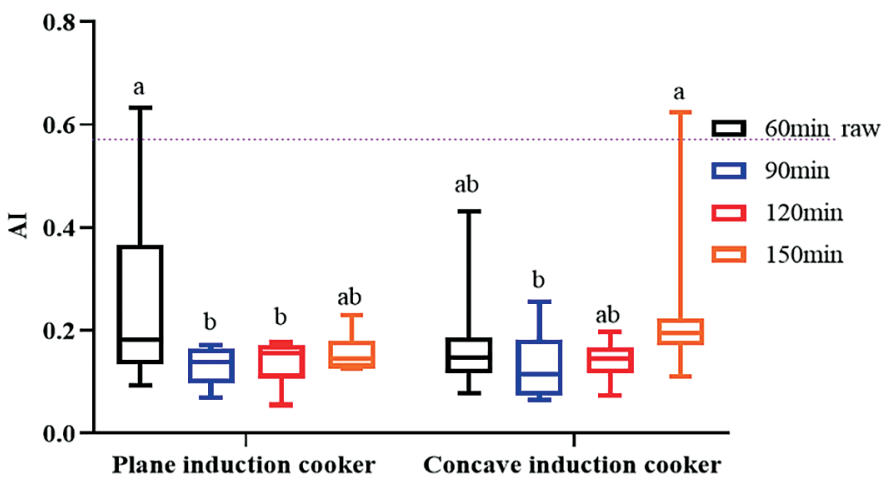

$\mathrm{G}$

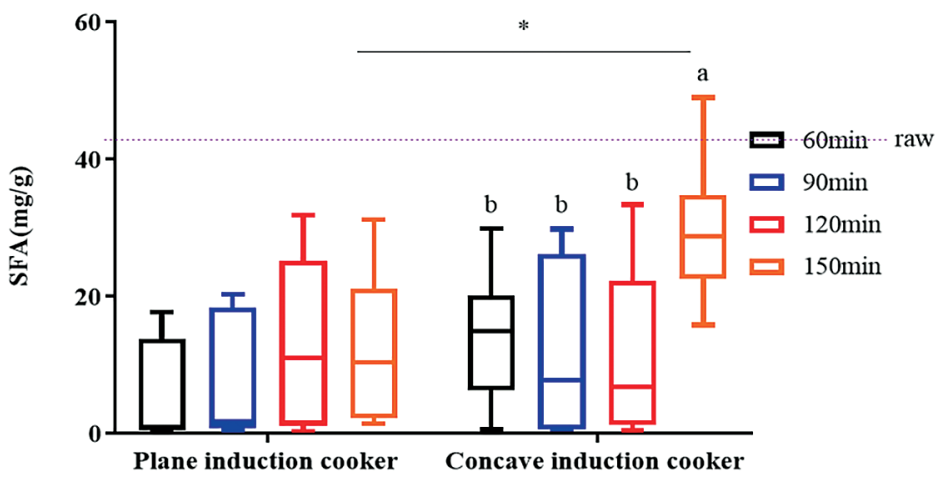

$\mathrm{B}$

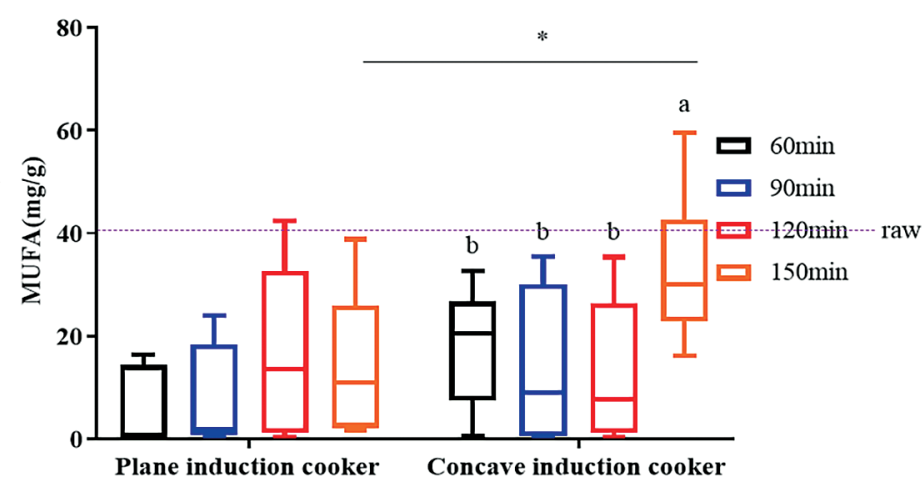

$\mathrm{D}$
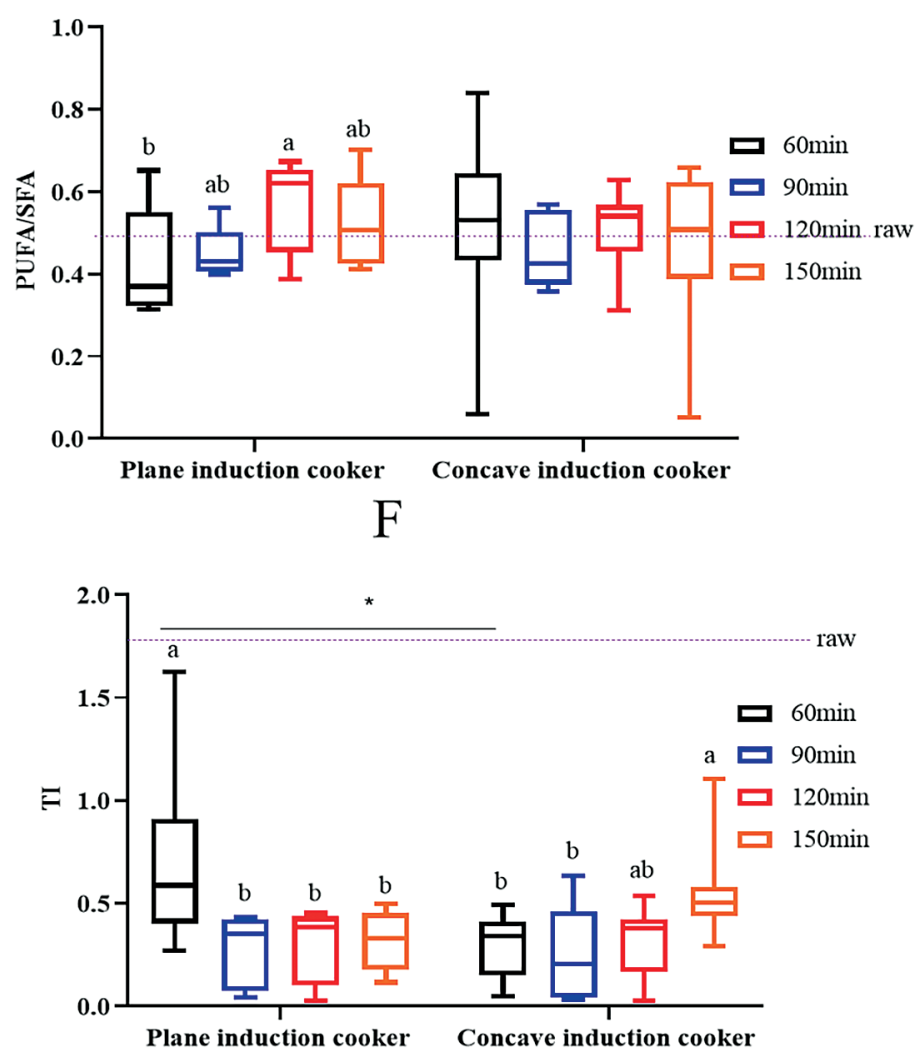

$\mathrm{H}$

a, b means differed significantly among cooking time points $(\mathrm{P}<0.05) .{ }^{*}$, significant differences existed between concave induction cooking and plane induction cooking at a certain time point $(\mathrm{P}<0.05)$.

Figure 4. Fatty acids profile of braised pork: A - medium chain fatty acids (MCT); B — saturated fatty acids (SFA);

$\mathrm{C}$ - unsaturated fatty acids (USA); D — monounsaturated fatty acids (MUFA); E — polyunsaturated fatty acids (PUFA) 


\section{Lipid and protein oxidation}

Lipid and protein oxidation showed great changes with cooking method and time $(\mathrm{P}<0.05$, Figure 5$)$. MDA is the secondary product of lipid oxidation. The MDA content in braised pork increased with cooking time in concave induction cooked pork but did not alter too much in plane induction cooked samples (Figure 5, A). The MDA value in meat samples cooked by concave induction for $60 \mathrm{~min}$ was similar to the values of plane induction cooked samples for $150 \mathrm{~min}$. The carbonyl content increased greatly with cooking time. The values at $150 \mathrm{~min}$ were higher in concave induction cooked samples than in plane induction cooked samples $(\mathrm{P}<0.05$, Figure 5, B). Correspondingly, the thiol content decreased greatly with cooking time and the values were always lower in concave induction cooked samples than in plane induction cooked samples $(\mathrm{P}<0.05$, Figure 5, $\mathrm{C})$. These results indicate that concave induction cooking may induce stronger lipid and protein oxidation. However, the carbonyl content of braised pork in concave induction cooker for $60 \mathrm{~min}$ was lower than that in plane induction cooker for $150 \mathrm{~min}(\mathrm{P}<0.05$, Figure $5 \mathrm{~B})$, and the thiol content was higher in concave induction cooker for $60 \mathrm{~min}$ than that in plane induction cooker for $150 \min (\mathrm{P}<0.05$, Figure 5, C). This indicates that much shorter cooking time of concave induction cooking can compensate its negative impacts on meat quality attributes.
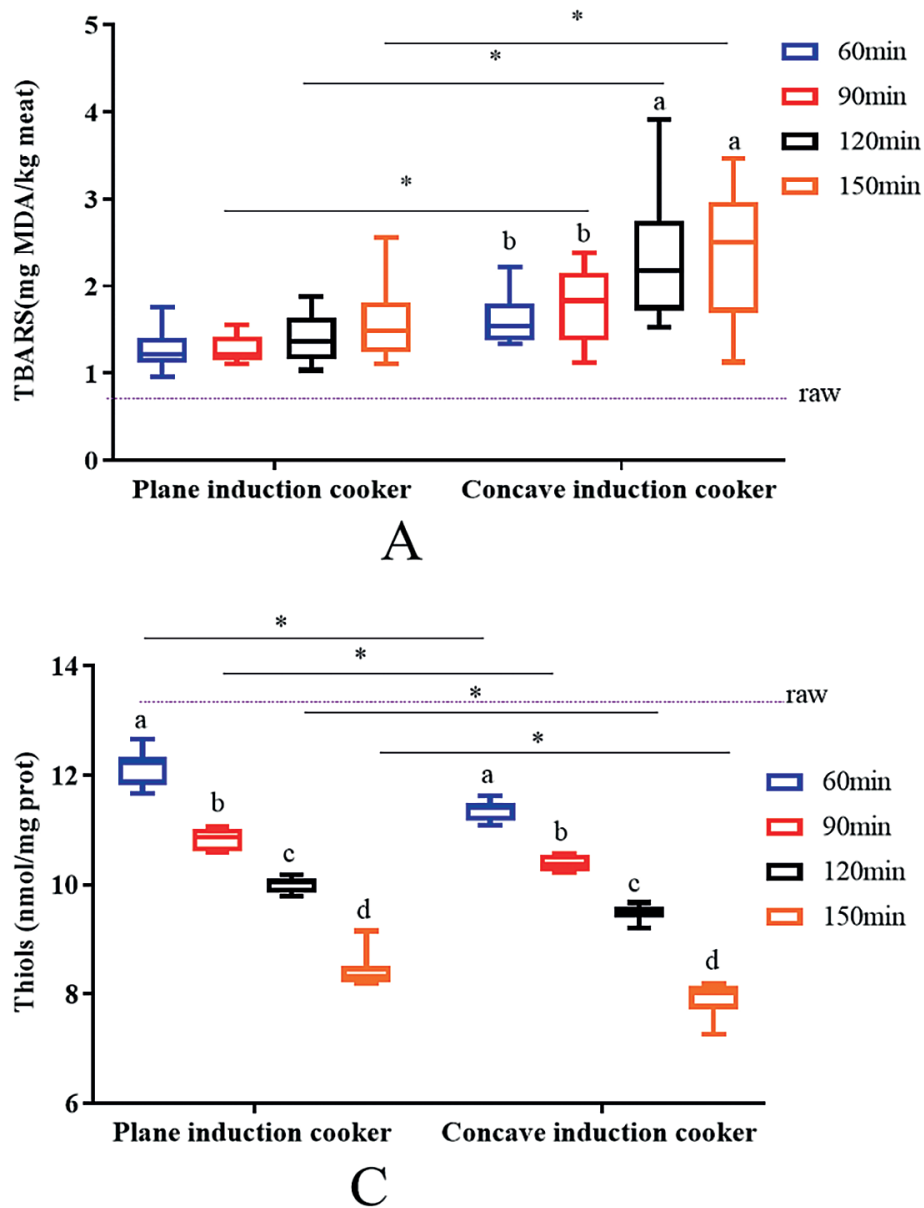

\section{E-nose}

E-nose is a sensitive technology to discriminate volatile compounds by different sensors. Principal component analysis showed that the first and second principal components (PCs) accounted for $94.22 \%$ and $3.55 \%$ of total variance of samples, respectively (Figure 6). Great differences were observed among samples cooked for different methods and times (ellipses A, C, E and G for plane induction cooking for $60 \mathrm{~min}, 90 \mathrm{~min}, 120 \mathrm{~min}$ and $150 \mathrm{~min}$, respectively; ellipses B, D, F and $\mathrm{H}$ for concave induction cooking for $60 \mathrm{~min}, 90 \mathrm{~min}, 120 \mathrm{~min}$ and $150 \mathrm{~min}$, respectively). PC1 mainly explained the variations caused by cooking method and cooking time. PC2 explained the variations from concave induction cooked samples for $120 \mathrm{~min}$. Samples cooked by concave induction for $60 \mathrm{~min}$ and $90 \mathrm{~min}$ showed a great similarity to those cooked by plane induction for $150 \mathrm{~min}$. The sensor signals indicate that the relative abundance of volatile compounds increased at the early stage due to chemical reactions such as lipid oxidation. Samples cooked by concave induction for $150 \mathrm{~min}$ overlaps with those cooked by plane induction for $60 \mathrm{~min}$, $90 \mathrm{~min}$ and $120 \mathrm{~min}$ (Table 5), which may be because some volatile compounds of braised pork in concave induction cooker were evaporated with moisture. Once again, cooking method affected E-nose metrics, which have to some degree been associated with flavor attributes. However,

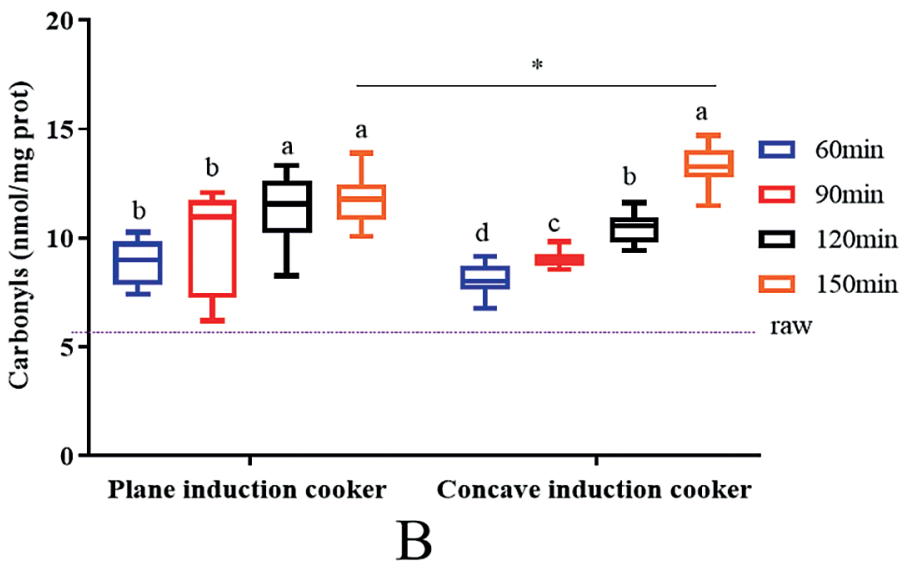

a, b, c, d means differed significantly among cooking time points $(\mathrm{P}<0.05)$. ${ }^{\star}$, significant differences existed between concave induction cooking and plane induction cooking at a certain time point $(\mathrm{P}<0.05)$.

Figure 5. Lipid and protein oxidation of braised pork 


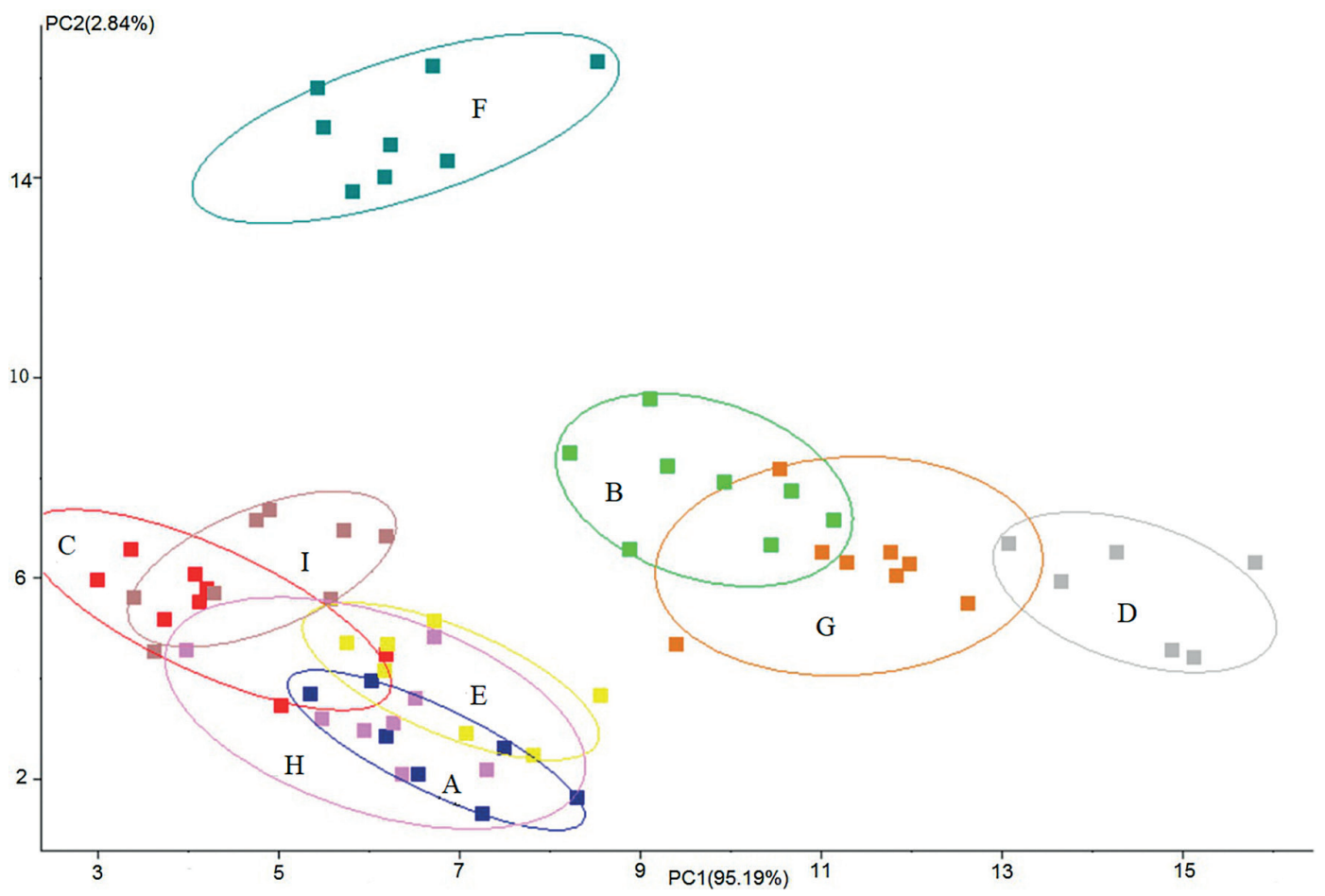

Figure 6. Principal component analysis scores plot for electronic nose data: A, C, E, G - concave induction cooking for 60 min, 90 min, $120 \mathrm{~min}$ and $150 \mathrm{~min}$, respectively; B, D, F, H — plane induction cooking for $60 \mathrm{~min}, 90 \mathrm{~min}, 120 \mathrm{~min}$ and 150 min, respectively; I — raw meat

the specific volatile compounds still need to be further identified by GC-MS.

\section{Volatile compounds}

During meat processing, heat-induced lipid oxidation and Maillard reaction of proteins are the main sources of meat flavor compounds. Lipid oxidation may produce aldehydes, ketones, esters, carboxylic acids, and aromatic hydrocarbons. Maillard reaction may produce pyrroles, pyrazines, furans, oxygen-containing heterocyclic compounds, Strecker aldehydes and carbonyl compounds [36].

Cooking methods have significant effect on the formation of volatile compounds in meat. For example, in pork loin, frying produces more pyrazines than hot air or an electric stove [37]. In cooked pork cheeks, cooking temperature and time have significant effects on volatile flavor compounds derived from lipid degradation and Maillard reactions [38]. In pork jerky, infrared grills produce more volatile flavor compounds at $200^{\circ} \mathrm{C}$ than at $150^{\circ} \mathrm{C}$ [39].

In the present study, we identified 72 volatile compounds in the lean part of braised pork that differed with cooking method or time $(\mathrm{P}<0.05$, Table 6$)$, including alcohols, nitrogen-containing compounds, aromatic hydrocarbons, phenols, furans, aldehydes, acids, ketones, aliphatic hydrocarbons and esters. Aldehydes were the most abundant volatile compounds in meat samples (Table 6). The identified aldehydes include nonanal, hexanal, benzaldehyde, (E, E)-2,4-decadienal, (2E)-2-octenal, (2E)-2-nonenal, octanal, pentadecanal, 5-ethylcyclopentene-1-carbaldehyde, hexadecanal and (E, E)-2,4-nonadienal. The abundance of most aldehydes decreased with cooking time. One exception is the hexadecanal whose abundance increased with cooking time $(\mathrm{P}<0.05$, Table 6$)$. The relative abundances of aldehydes in the concave induction cooker for $60 \mathrm{~min}$ were similar to those cooked by plane induction for $150 \mathrm{~min}$. This may be due to the stronger oxidation of fatty acids in concave induction cooked samples. The low thresholds of aldehydes contribute significantly to the flavor of braised pork [40]. Nonanal was one of the most abundant aldehydes in this study, which is a major oxidation product of oleic acid [41] and has fat aroma [42]. Benzaldehyde, which is derived from Strecker degradation of amino acids $[43,44]$, was also highly abundant and its content in samples cooked by concave induction for $60 \mathrm{~min}$ was similar to those cooked by plane induction for $150 \mathrm{~min}$ (Table 6).

Concave induction cooking for $60 \mathrm{~min}$ also showed advantages to retain higher abundances of other volatile compounds including 2-pentylfuran, (E, E)-3,5-octadien-2-one, 2, 3-octanedione, 2-decahydro-1,6- dimethylnaphthalene when compared with plane induction cooking for $150 \mathrm{~min}$ (Table 6). 2-Pentylfuran has been reported to contribute to the flavor of meat [45], was the only detectable furan. (E, E)-3,5-octadien-2-one and 2, 3-octanedione may contribute to a butter aroma in meat products. 2-Decahydro-1,6-dimethylnaphthalene has grass-like aroma. In the present study, such compounds could be derived from vegetable oil, soy sauce or wine. Concave induction cooking can retain higher volatile compounds, which should be attributed to higher cooking temperature. Higher cooking temperature may produce more volatile flavor compounds through Maillard reaction and Strecker degradation [46] and improve the taste and volatile flavor of stewed pork [47]. Taken together, the volatile compound profile in braised pork prepared in a concave induction cooker for 60 min may be better than that in a plane induction cooker for $150 \mathrm{~min}$. 


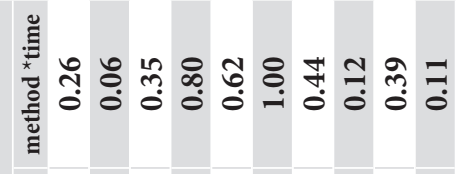

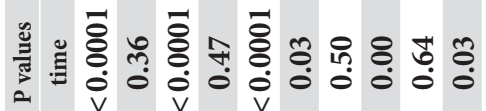

产

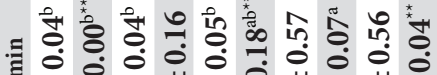

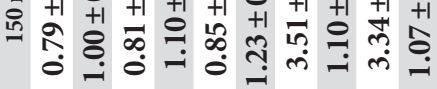

:

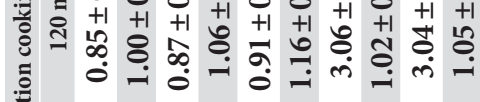

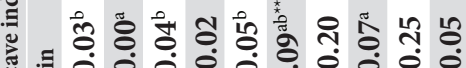

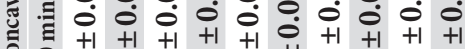

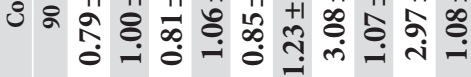

นั้

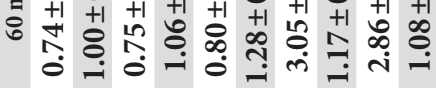

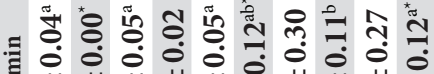

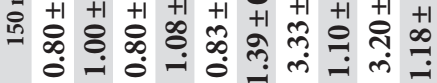

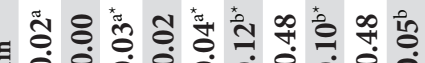

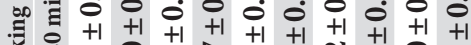
亦

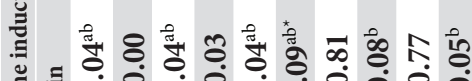

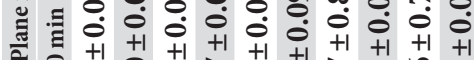

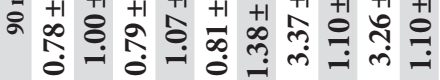

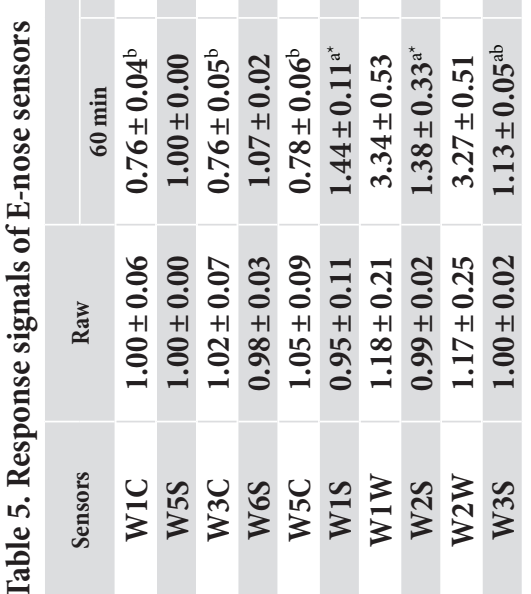

\section{$\bar{\approx}$}

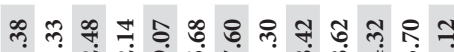

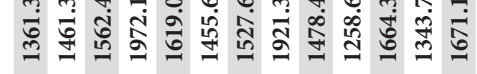
рочриш

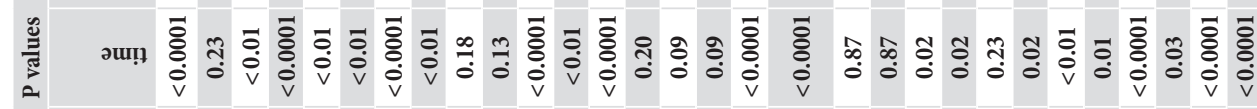

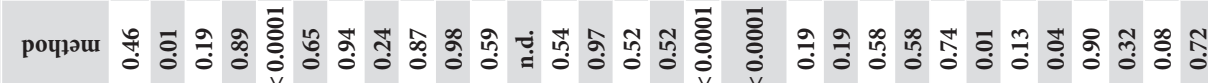
总

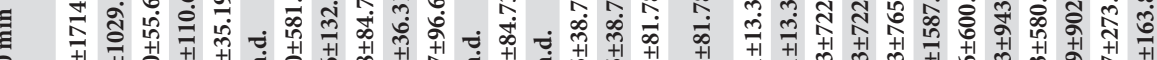

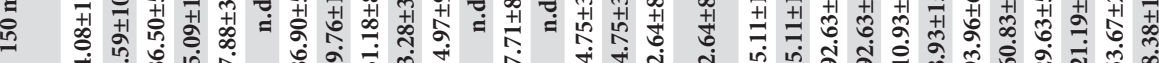

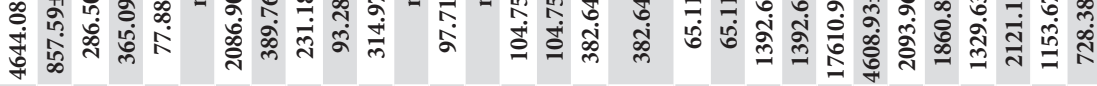

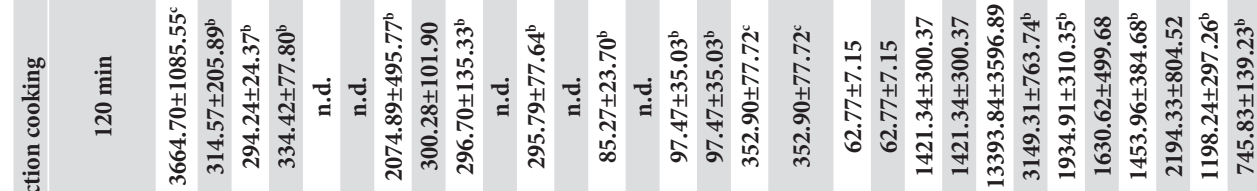
के

สุ่

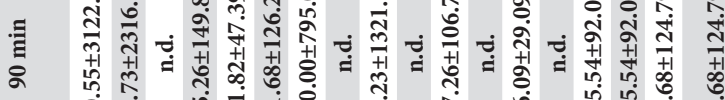

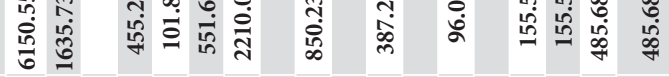

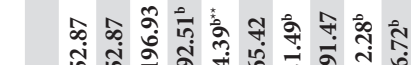

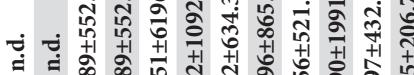

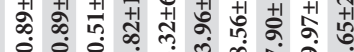

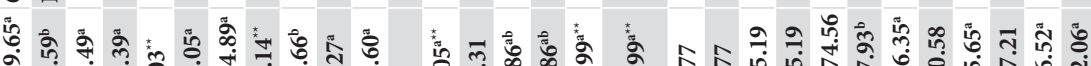

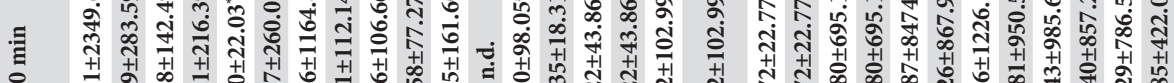

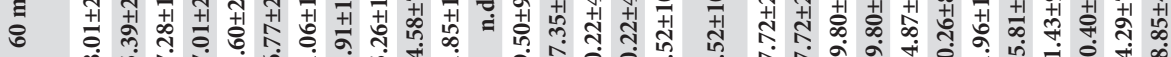

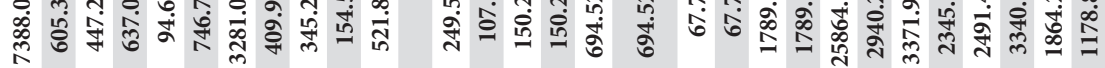

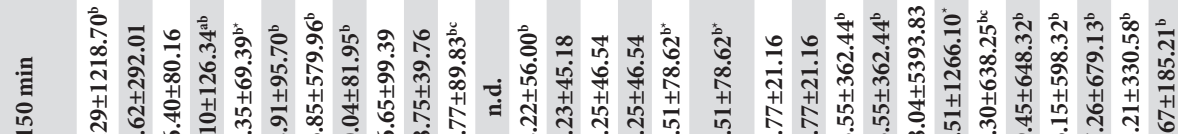

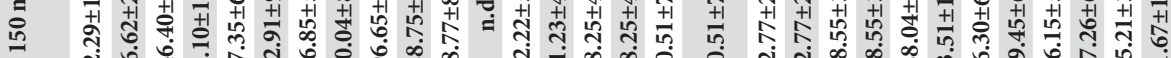

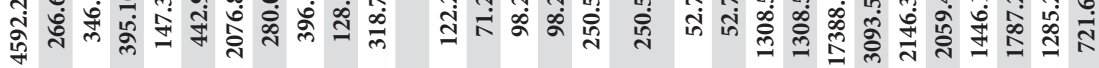

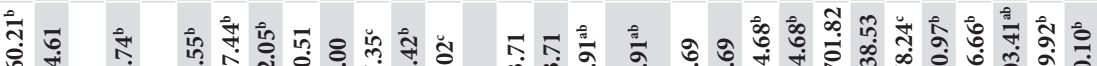

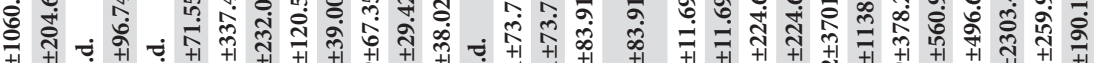

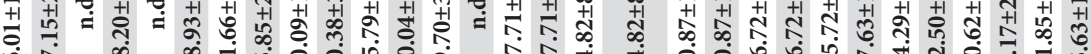

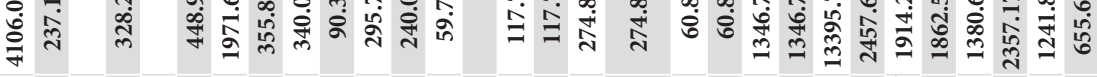

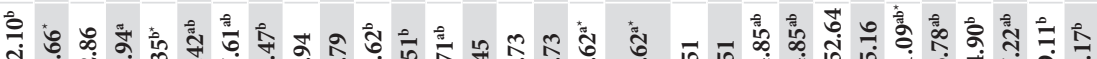

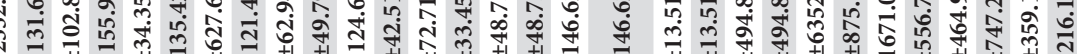

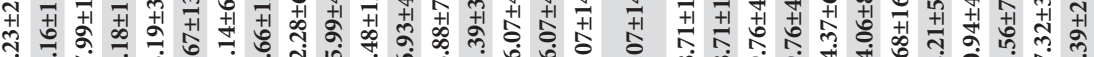

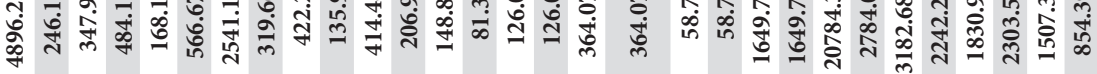

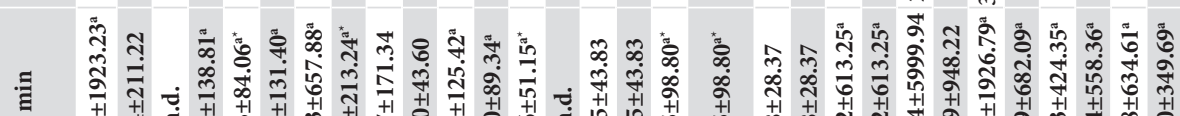

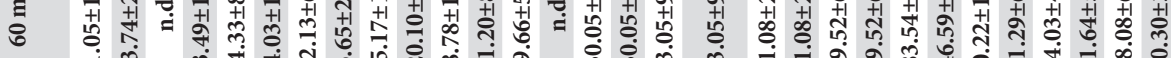

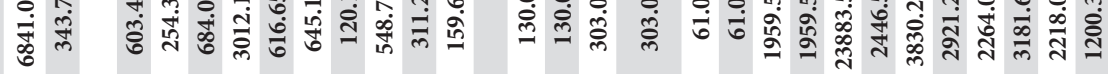

ती तु प)

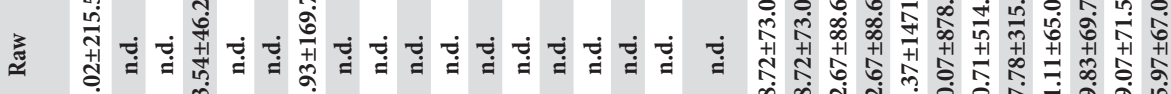
究

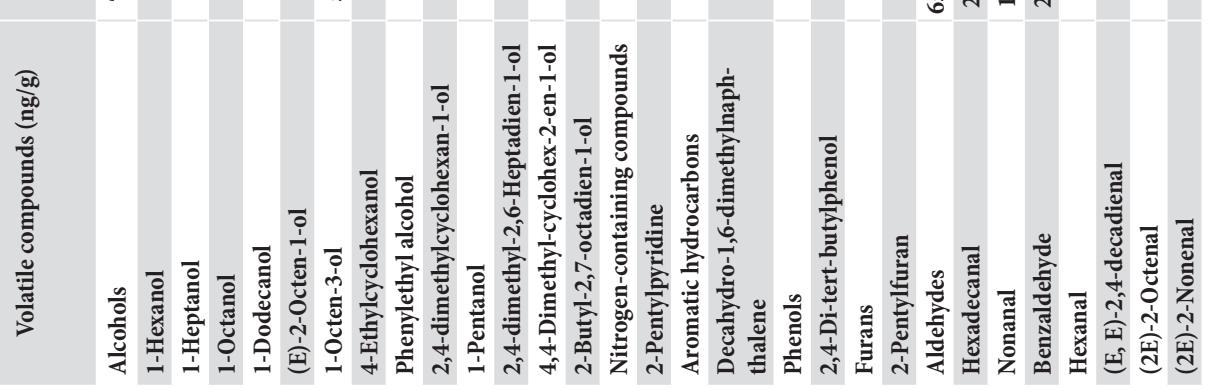




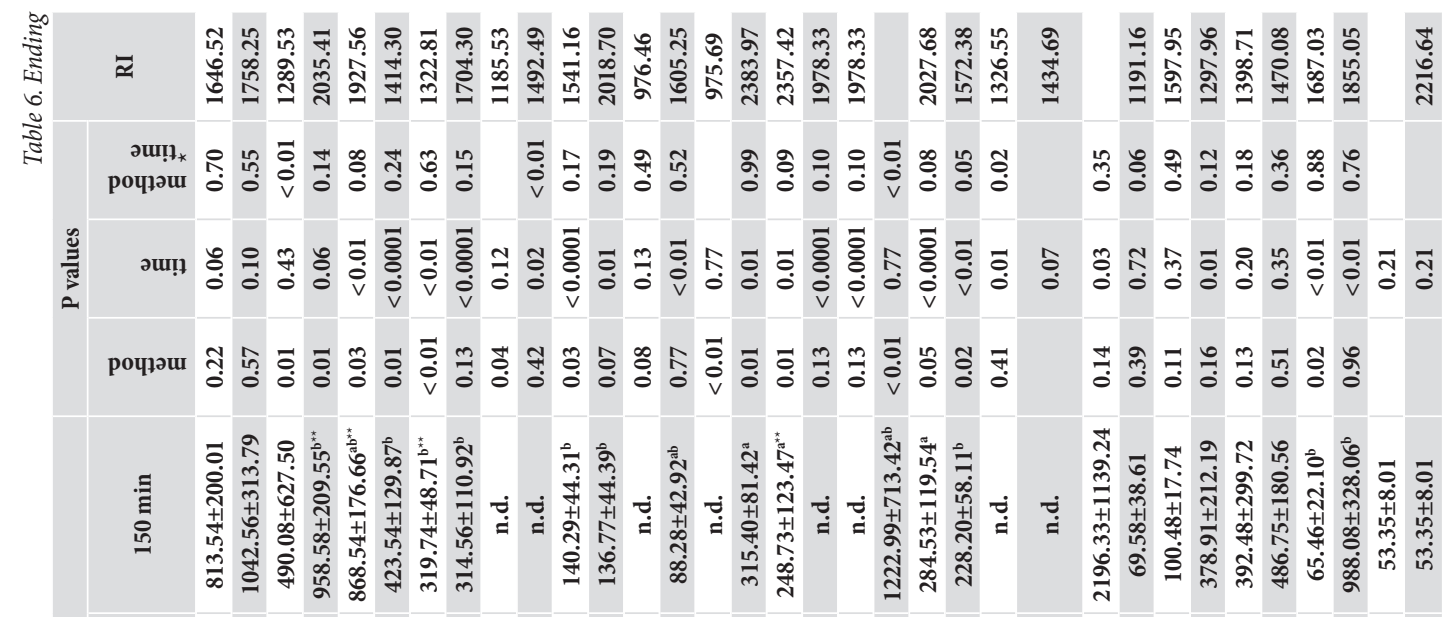

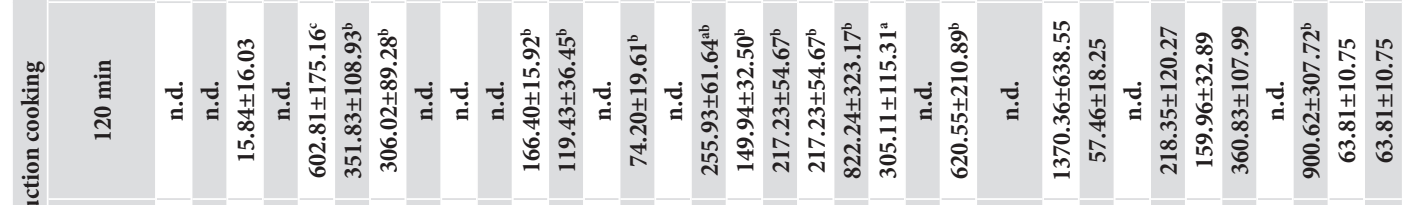

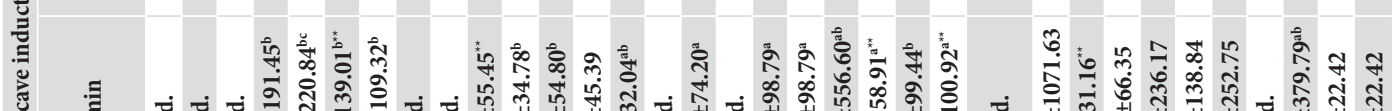

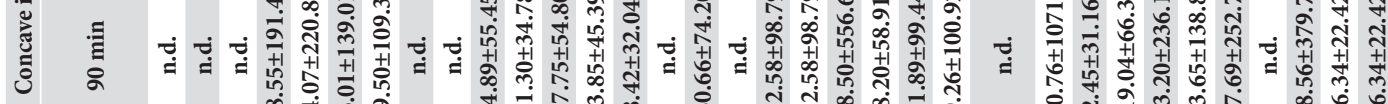

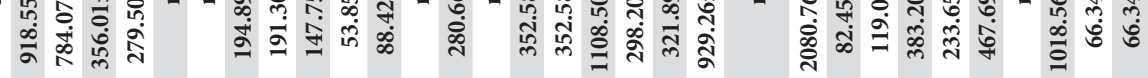

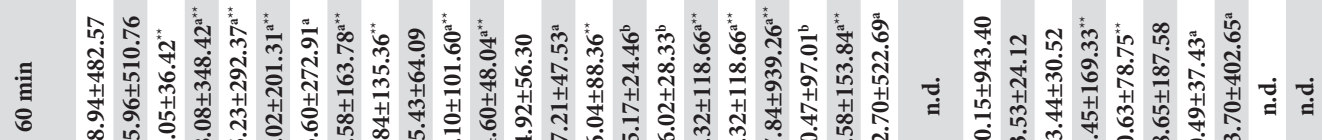

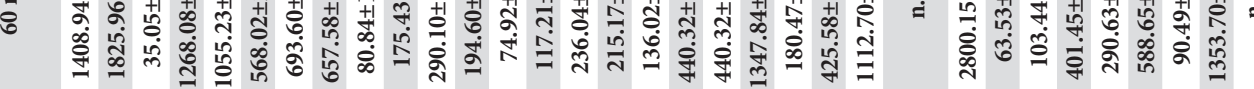

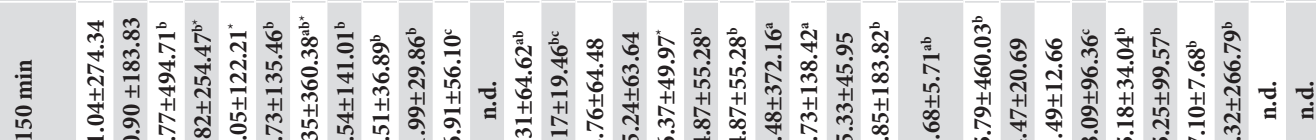

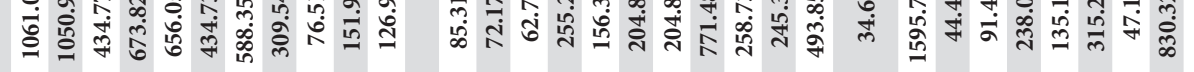

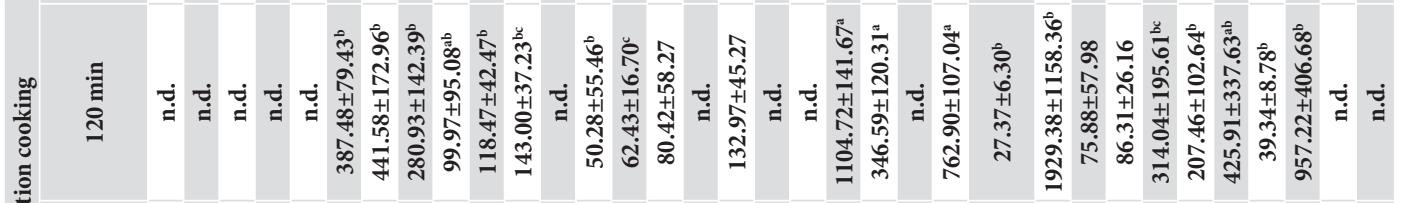

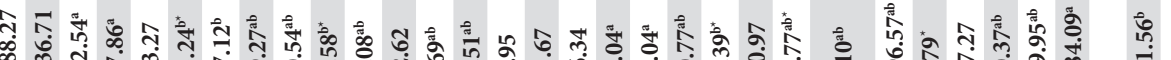

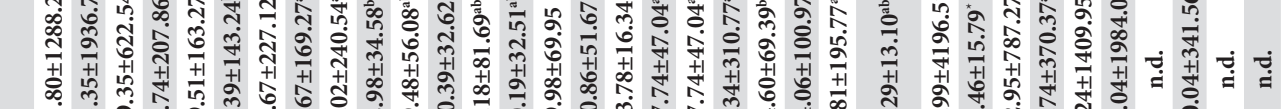

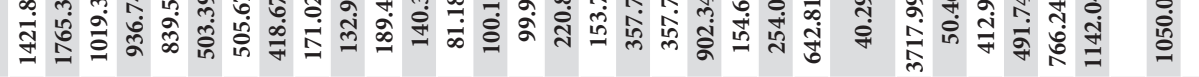

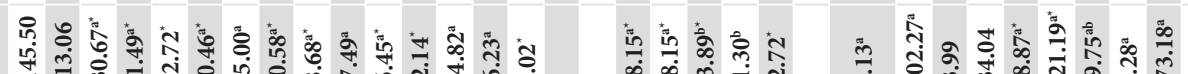

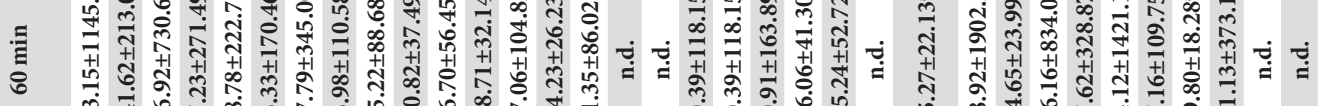

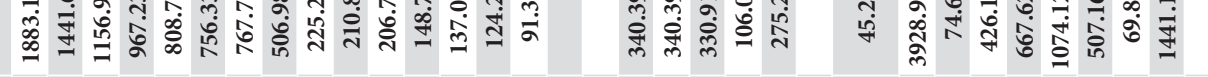

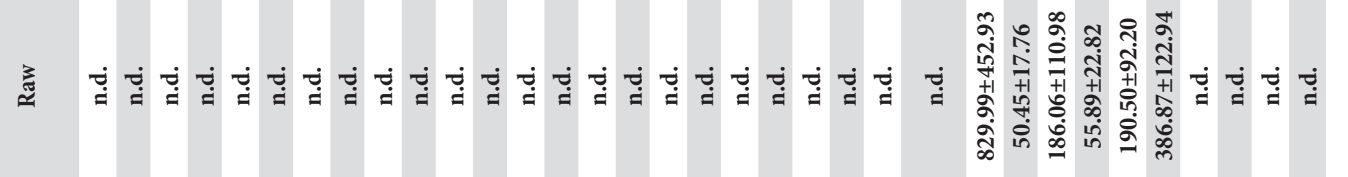

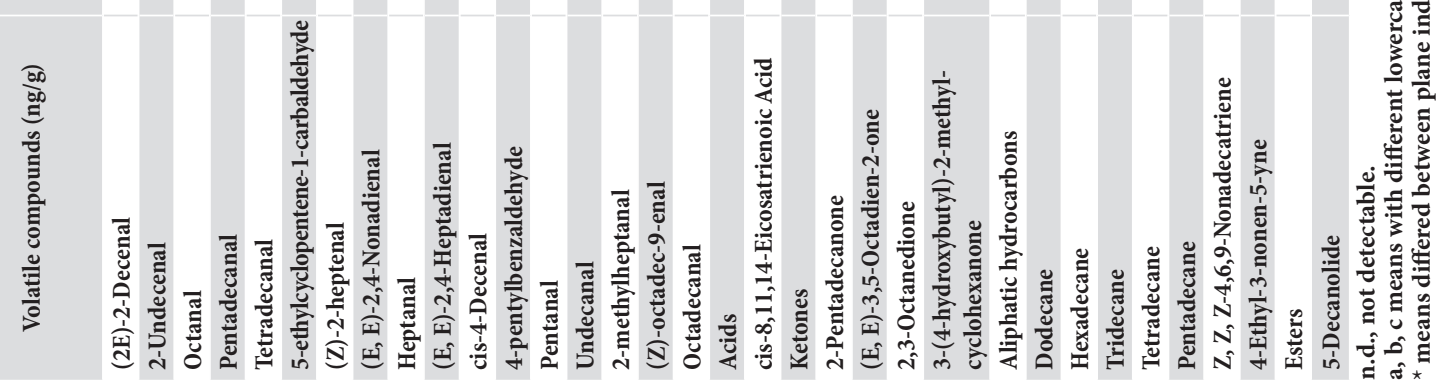

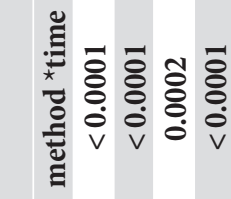

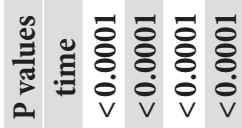

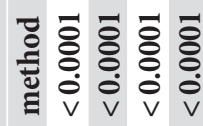

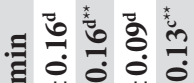

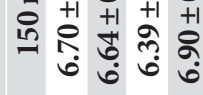

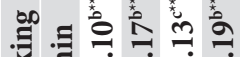

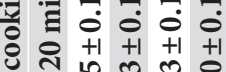
艾

כ

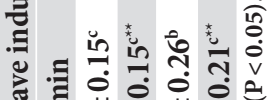
U. ठٌ

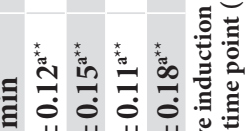

8
8
0

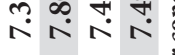

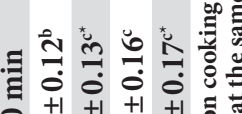

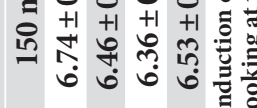

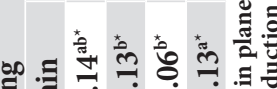

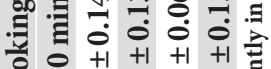

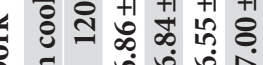
完

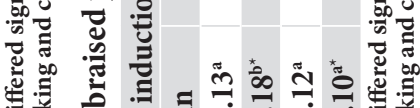

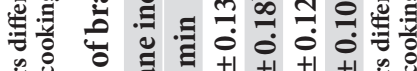

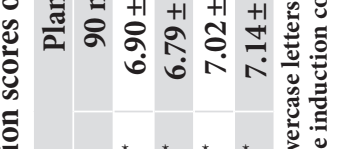

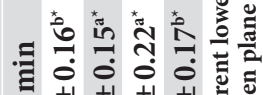

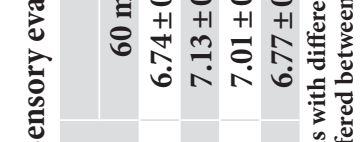
m.

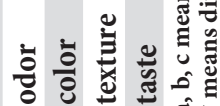




\section{Sensory evaluation}

For plane induction cooked samples, the odor and taste scores increased from $60 \mathrm{~min}$ to $90 \mathrm{~min}$ but decreased afterwards $(\mathrm{P}<0.05$, Table 7$)$. The color and texture scores decreased as cooking time increased $(\mathrm{P}<0.05)$. For concave induction cooked samples, the color and texture scores decreased during the whole cooking period. The odor and taste scores decreased from $60 \mathrm{~min}$ to $90 \mathrm{~min}$ with a small increase from $90 \mathrm{~min}$ to $120 \mathrm{~min}$, and subsequent decrease from $120 \mathrm{~min}$ to $150 \mathrm{~min}(\mathrm{P}<0.05)$. The greatest values were observed in concave induction cooked samples for $60 \mathrm{~min}(\mathrm{P}<0.05$, Table 7$)$. Such a difference was in accordance with the results of sensory evaluation. In previous studies, E-nose sensor signals were shown to have a certain correlation with sensory attributes $[48,49]$.

As mentioned above, concave induction cooking had higher energy efficiency and lower energy consumption. The center temperatures of the meat samples near the center of the cookers were higher in the concave induction cooker. The higher temperature may cause greater changes in myofibrillar proteins to produce better texture. The higher heating efficiency also leads to the release of more structural lipids (mainly PUFA). In addition, the lipid oxidation and protein oxidation were not serious in concave induction cooked samples for a shorter time. Volatile compounds are mainly derived from lipid oxidation and Maillard reaction. Higher cooking temperature for a short time can also increase the content of volatile compounds and sensory scores. Therefore, concave induction cooking can improve the texture and flavor of braised pork in a short time, which may be due to better heating efficiency.

\section{Conclusion}

In this study, concave induction cooking was shown to have higher cooking efficiency and exhibited a significant impact on the texture, fatty acid composition, lipid and protein oxidation, volatile flavor and sensory evaluation in braised pork compared with plane induction cooking. At a power of $2000 \mathrm{~W}$, concave induction cooking for $60 \mathrm{~min}$ produced a comparable or better level of texture, fatty acid profile, lipid and protein oxidation, flavor and sensory scores to plane induction cooking for $150 \mathrm{~min}$. Thus, concave induction cooking is a promising alternative for traditional long-term and high-temperature cooking in meat products.

\section{REFERENCES}

1. Lucia, O., Maussion, P., Dede, E. J., Burdio, J. M. (2014). Induction heating technology and its applications: past developments, current technology, and future challenges. IEEE Transactions on Industrial Electronics, 61(5), 2509-2520, Article 6595059. https://doi.org/10.1109/TIE.2013.2281162

2. El-Mashad, H. M., Pan, Z. (2017). Application of induction heating in food processing and cooking. Food Engineering Reviews, 9(2), 82-90. https://doi.org/10.1007/s12393-016-9156-0

3. Martinez-Gomez, J. (2017). Analysis of physicochemical and microbiological measurements of food prepared using different stoves. Carpathian Journal of Food Science and Technology, 9(1), 68-79.

4. Zouambia, Y., Youcef Ettoumi, K., Krea, M., Moulai-Mostefa, N. (2017). A new approach for pectin extraction: Electromagnetic induction heating. Arabian Journal of Chemistry, 10(4), 480-487. https://doi.org/10.1016/j.arabjc.2014.11.011

5. Başaran, A., Yilmaz, T., Çivi, C. (2018). Application of inductive forced heating as a new approach to food industry heat exchangers. Journal of Thermal Analysis and Calorimetry, 134(3), 2265-2274. https://doi.org/10.1007/s10973-018-7250-7

6. Acero, J., Burdio, J., Barragan, L., Navarro, D., Alonso, R., Ramon, J. et al. (2010). Domestic induction appliances. IEEE Industry Applications Magazine, 16(2), 39-47, Article 5411854. https://doi.org/10.1109/MIAS.2009.935495

7. Meng, L., Cheng, K. W. E., Chan, K. W. (2011). Systematic approach to high-power and energy-efficient industrial induction cooker system: circuit design, control strategy, and prototype evaluation. IEEE Transactions on Power Electronics, 26(12), 3754-3765, Article 5986727. https://doi.org/10.1109/ TPEL.2011.2165082

8. Chao, N. (1997). Concave induction cooking surface for wok cooking. Patent, US5687642 A. https://doi.org/US5687642 A

9. Dong, X., Fu, H., Chang, S., Zhang, X., Sun, H., He, B. et al. (2017). Textural and biochemical changes of scallop patinopectenyessoensis adductor muscle during low-temperature long-time (LTLT) processing. International Journal of Food Properties, 20, S2495-S2507. https://doi.org/10.1080/10942912.2017.1373123

10. Qi, J., Liu, D. -Y., Zhou, G. -H., Xu, X.-L. (2017). Characteristic flavor of traditional soup made by stewing Chinese yellowfeather chickens. Journal of Food Science, 82(9), 2031-2040. https://doi.org/10.1111/1750-3841.13801

11. Qi, J., Li, X., Zhang, W., Wang, H., Zhou, G., Xu, X. (2018). Influence of stewing time on the texture, ultrastructure and in vitro digestibility of meat from the yellow-feathered chicken breed. Animal Science Journal, 89(2), 474-482. https://doi.org/10.1111/ asj.12929
12. Li, Y., Li, C., Li, H., Lin, X., Deng, S., Zhou, G. (2016). Physicochemical and fatty acid characteristics of stewed pork as affected by cooking method and time. International Journal of Food Science and Technology, 51(2), 359-369. https://doi.org/10.1111/ijfs.12968 13. Chen, Y., Zhou, G., Zhu, X., Xu, X., Tang, X., Gao, F. (2007). Effect of low dose gamma irradiation on beef quality and fatty acid composition of beef intramuscular lipid. Meat Science, 75(3), 423-431. https://doi.org/10.1016/j.meatsci.2006.08.014

14. Campo, M., Muela, E., Olleta, J., Moreno, L., SantaliestraPasías, A., Mesana, M. et al. (2013). Influence of cooking method on the nutrient composition of Spanish light lamb. Journal of Food Composition and Analysis, 31(2), 185-190. https://doi. org/10.1016/j.jfca.2013.05.010

15. Soladoye, O., Shand, P., Dugan, M., Gariépy, C., Aalhus, J., Estévez, M. et al. (2017). Influence of cooking methods and storage time on lipid and protein oxidation and heterocyclic aromatic amines production in bacon. Food Research International, 99, 660-669. https://doi.org/10.1016/j.foodres.2017.06.029 16. Oliver, C. N., Ahn, B. -W., Moerman, E. J., Goldstein, S., Stadtman, E. R. (1987). Age-related changes in oxidized proteins. Journal of Biological Chemistry, 262(12), 5488-5491.

17. Lund, M. N., Lametsch, R., Hviid, M. S., Jensen, O. N., Skibsted, L. H. (2007). High-oxygen packaging atmosphere influences protein oxidation and tenderness of porcine longissimus dorsi during chill storage. Meat Science, 77(3), 295-303. https://doi. org/10.1016/j.meatsci.2007.03.016

18. Huang, X. -H., Qi, L. -B., Fu, B. -S., Chen, Z. -H., Zhang, Y. -Y., Du, M. et al.. (2019). Flavor formation in different production steps during the processing of cold-smoked Spanish mackerel. Food Chemistry, 286, 241-249. https://doi.org/10.1016/j.foodchem.2019.01.211 19. Xu, Y., Liu, Y., Jiang, C., Zhang, C., Li, X., Zhu, D. et al. (2014). Determination of volatile compounds in turbot (psetta maxima) during refrigerated storage by headspace solid-phase microextraction and gas chromatography-mass spectrometry. Journal of the Science of Food and Agriculture, 94(12), 2464-2471. https://doi.org/10.1002/jsfa.6581

20. Wang, R., Huang, F., Zhang, L., Liu, Q., Zhang, C., Zhang, $H_{\text {. }}$ (2019). Changes in the texture, microstructures, colour and volatile compounds of pork meat loins during superheated steam cooking. International Journal of Food Science \& Technology, 54(10), 2821-2830. https://doi.org/10.1111/ijfs.14198

21. Meng, L., Cheng, K., Chan, K. (2009). Heating performance improvement and field study of the induction cooker. In 3rd International Conference on Power Electronics Systems and Applications, Article 5228679. 
22. Jiang, Q., Han, J., Gao, P., Yu, L., Xu, Y., Xia, W. (2018). Effect of heating temperature and duration on the texture and protein composition of Bighead Carp (Aristichthys nobilis) muscle. International Journal of Food Properties, 21(1), 2110-2120. https://doi.org/10.1080/10942912.2018.1489835

23. He, S., Elfalleh, W., Sun, X., Du, M., Chen, H., Sun, H. et al. (2019). Quality and sensory characteristics of volutharpa ampullaceal perryi (false sbalone) meat during the boiling cooking. Journal of Aquatic Food Product Technology, 28(1), 93-106. https://doi.org/10.1080/10498850.2018.1562502

24. Nagao, K., Yanagita, T. (2010). Medium-chain fatty acids: functional lipids for the prevention and treatment of the metabolic syndrome. Pharmacological Research, 61(3), 208-212. https://doi.org/10.1016/j.phrs.2009.11.007

25. Mashek, D. G., Wu, C. (2015). MUFAs. Advances in Nutrition, 6(3), 276-277. https://doi.org/10.3945/an.114.005926

26. Gerber, N., Scheeder, M., Wenk, C. (2009). The influence of cooking and fat trimming on the actual nutrient intake from meat. Meat Science, 81(1), 148-154. https://doi.org/10.1016/j.meatsci.2008.07.012

27. Kouba, M., Benatmane, F., Blochet, J. E., Mourot, J. (2008). Effect of a linseed diet on lipid oxidation, fatty acid composition of muscle, perirenal fat, and raw and cooked rabbit meat. Meat Science, 80(3), 829-834. https://doi.org/10.1016/j.meatsci.2008.03.029 28. Bi, X., Yeo, P. L. Q., Loo, Y. T., Henry, C. J. (2019). Associations between circulating fatty acid levels and metabolic risk factors. Journal of Nutrition and Intermediary Metabolism, 15, 65-69. https://doi.org/10.1016/j.jnim.2019.02.002

29. Kahleova, H., Barnard, N. D. (2019). Serial measures of circulating biomarkers of dairy fat: something is missing. The American Journal of Clinical Nutrition, 109(1), 219-220. https://doi. org/10.1093/ajcn/nqy277

30. Salcedo-Sandoval, L., Cofrades, S., Ruiz-Capillas Pérez, C., Solas, M. T., Jiménez-Colmenero, F. (2013). Healthier oils stabilized in konjac matrix as fat replacers in n-3 PUFA enriched frankfurters. Meat Science, 93(3), 757-766. https://doi.org/10.1016/j. meatsci.2012.11.038

31. Ulbricht, T.L.V., Southgate, D.A.T. (1991). Coronary heart disease: seven dietary factors. The Lancet, 338(8773), 985-992. https://doi.org/10.1016/0140-6736(91)91846-M

32. Soriano, A., Cruz, B., Gómez, L., Mariscal, C., García Ruiz, A. (2006). Proteolysis, physicochemical characteristics and free fatty acid composition of dry sausages made with deer (cervus elaphus) or wild boar (sus scrofa) meat: a preliminary study. Food Chemistry, 96(2), 173-184. https://doi.org/10.1016/j.foodchem.2005.02.019 33. Simopoulos, A. P. (2004). Omega-6/omega-3 essential fatty acid ratio and chronic diseases. Food Reviews International, 20(1), 77-90. https://doi.org/10.1081/FRI-120028831

34. Dugan, M. E. R., Vahmani, P., Turner, T. D., Mapiye, C., Juarez, M., Prieto, N.et al. (2015). Pork as a source of omega-3 (n-3) fatty acids. Journal of Clinical Medicine, 4(12), 1999-2011. https://doi.org/10.3390/jcm4121956

35. Halagarda, M., Kdzior, W., Pyrzynska, E., Kudeka, W. (2018). Fatty acid compositions of selected Polish pork hams and sausages as influenced by their traditionality. Sustainability (Switzerland), 10(11), Article 3885. https://doi.org/10.3390/su10113885

36. Mottram, D. S. (1998). Flavour formation in meat and meat products: a review. Food Chemistry, 62(4), 415-424. https://doi. org/10.1016/S0308-8146(98)00076-4
37. Yang, Z., Lu, R., Song, H., Zhang, Y., Tang, J., Zhou, N. (2016). Effect of different cooking methods on the formation of aroma components and heterocyclic amines in pork loin. Journal of Food Processing and Preservation, 41(3), Article e12981. https://doi. org/10.1111/jfpp.12981

38. Del Pulgar, J. S., Roldan, M., Ruiz-Carrascal, J. (2013). Volatile compounds profile of sous-vide cooked pork cheeks as affected by cooking conditions (vacuum packaging, temperature and time). Molecules, 18(10), 12538-12547. https://doi. org/10.3390/molecules181012538

39. Chen, W. S., Liu, D. C., Chen, M. T. (2002). The effect of roasting temperature on the formation of volatile compounds in Chinese-style pork jerky. Asian-Australasian Journal of Animal Sciences, 15(3), 427-431. https://doi.org/10.5713/ajas.2002.427 40. Song, S., Fan, L., Xu, X., Xu, R., Jia, Q., Feng, T. (2019). Aroma patterns characterization of braised pork obtained from a novel ingredient by sensory-guided analysis and gas-chromatography-olfactometry. Foods, 8(3), Article 87. https://doi.org/10.3390/foods8030087 41. García-Llatas, G., Lagarda, M. J., Romero, F., Abellán, P., Farré, R. (2007). A headspace solid-phase microextraction method of use in monitoring hexanal and pentane during storage: Application to liquid infant foods and powdered infant formulas. Food Chemistry, 101(3), 1078-1086. https://doi.org/10.1016/j.foodchem.2006.03.007

42. Denk, P., Buettner, A. (2018). Identification and quantification of glue-like off-odors in elastic therapeutic tapes. Analytical and Bioanalytical Chemistry, 410(14), 3395-3404. https://doi. org/10.1007/s00216-018-1046-2

43. Griffith, R., Hammond, E. G. (1989). Generation of Swiss cheese flavor components by the reaction of amino acids with carbonyl compounds. Journal of Dairy Science, 72(3), 604-613. https://doi.org/10.3168/jds.S0022-0302(89)79150-5

44. Ji, S., Gu, S., Wang, X., Wu, N. (2015). Comparison of olfactometrically detected compounds and aroma properties of four different edible parts of Chinese mitten crab. Fisheries Science, 81(6), 1157-1167. https://doi.org/10.1007/s12562-015-0925-0

45. Gu, S. -Q., Wang, X. -C., Tao, N. -P., Wu, N. (2013). Characterization of volatile compounds in different edible parts of steamed Chinese mitten crab (eriocheirsinensis). Food Research International, 54(1), 81-92. https://doi.org/10.1016/j. foodres.2013.05.018

46. Luo, J., Nasiru, M. M., Zhuang, H., Zhou, G., Zhang, J. (2021). Effects of partial $\mathrm{NaCl}$ substitution with high-temperature ripening on proteolysis and volatile compounds during process of Chinese dry-cured lamb ham. Food Research International, 140, Article 110001. https://doi.org/10.1016/j.foodres.2020.110001 47. Han, D., Zhang, C. -H., Fauconnier, M. -L., Jia, W., Wang, J. -F., Hu, F. -F. et al. (2021). Characterization and comparison of flavor compounds in stewed pork with different processing methods. LWT, 144, Article 111229. https://doi.org/10.1016/j.Iwt.2021.111229

48. Da, D., Nian, Y., Shi, J., Li, Y., Zhao, D., Zhang, G., Li, C. (2021). Characterization of specific volatile components in braised pork with different tastes by SPME-GC/MS and electronic nose. Journal of Food Processing and Preservation, 45(5), Article e15492. https://doi.org/10.1111/jfpp.15492.

49. Xu, Y., Chen, Y.P., Deng, S., Li, C., Xu, X., Zhou, G., Liu, Y. (2020). Application of sensory evaluation, GC-ToF-MS, and E-nose to discriminate the flavor differences among five distinct parts of the Chinese blanched chicken. Food Research International, 137, Article 109669. http://doi.org/10.1016/j.foodres.2020.109669.

\section{AUTHOR INFORMATION:}

Dandan Da, Master, College of Food Science and Technology, Nanjing Agricultural University. Weigang 1\#, 210095, Nanjing. China. Tel.: +86-25-843-95-679, E-mail: 2017108028@njau.edu.cn

ORCID: http://orcid.org/0000-0002-5909-0982

* Corresponding author

Chunbao Li, PhD, Professor, College of Food Science and Technology, Nanjing Agricultural University, Weigang 1\#, 210095, Nanjing, P. R. China. Tel.: +86-25-843-95-679, E-mail: chunbao.li@njau.edu.cn

ORCID: http://orcid.org/ 0000-0002-4764-1994

All authors are responsible for the work and data presented.

All authors made an equal contribution to the work.

The authors were equally involved in writing the manuscript and are equally responsible for plagiarism.

The authors declare no conflict of interest. 